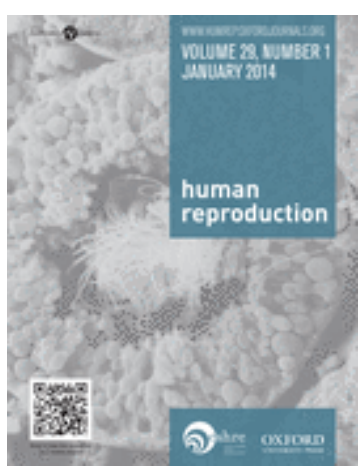

Draft Manuscript For Review. Reviewers should submit their review at http://mc.manuscriptcentral.com/humrep

\title{
Research Funding for Male Reproductive Health and Infertility in the UK and USA [2016 - 2019]
}

\begin{tabular}{|c|c|}
\hline Journal: & Human Reproduction \\
\hline Manuscript ID & Draft \\
\hline Manuscript Type: & Original Article \\
\hline $\begin{array}{r}\text { Date Submitted by the } \\
\text { Author: }\end{array}$ & $\mathrm{n} / \mathrm{a}$ \\
\hline Complete List of Authors: & $\begin{array}{l}\text { Gumerova, Eva; University of Dundee College of Life Sciences, Life } \\
\text { Sciences } \\
\text { De Jonge, Christopher; University of Minnesota Medical Center } \\
\text { University of Minnesota. } 606 \text { 24th Avenue South, Suite 525, Minneapolis, } \\
\text { MN 55454, USA, Department of Urology, } \\
\text { Barratt, C; University of Dundee, Maternal \& Child Heath Sciences; }\end{array}$ \\
\hline Keywords: & $\begin{array}{l}\text { ANDROLOGY, FEMALE INFERTILITY, MALE INFERTILITY, SPERM } \\
\text { QUALITY, TESTIS }\end{array}$ \\
\hline Subject Section: & Andrology \\
\hline
\end{tabular}

\section{SCHOLARONE ${ }^{\mathrm{m}}$ Manuscripts}


Gumerova, De Jonge and Barratt - August 19th, 2021

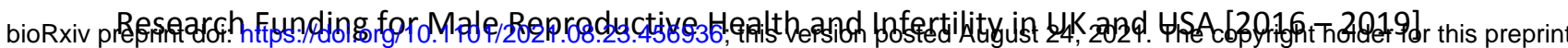
(which was not certified by peer review) is the author/funder, who has granted bioRxiv a license to display the preprint in perpetuity. It is made 1 available under aCC-BY-NC-ND 4.0 International license.

2

Authors and Affiliations:

6

7

8

9

10
Eva Gumerova

Christopher J. De Jonge

Christopher L.R. Barratt

Eva Gumerova:

School of Life Sciences, University of Dundee. Dundee, DD1 4HN, UK. egumerova@dundee.ac.uk ORCID: 0000-0002-2585-3769

Christopher J. De Jonge:

University of Minnesota Medical Center, Department of Urology, University of Minnesota. 606 24th Avenue South, Suite 525, Minneapolis, MN 55454, USA. Christopher.DeJonge@fairview.org ORCID: 0000-0002-4083-5833

Christopher L.R. Barratt*:

Division of Systems Medicine, School of Medicine, Ninewells Hospital and Medical School, University of Dundee, Dundee, DD1 9SY, UK. c.barratt@dundee.ac.uk ORCID: 0000-0003-0062-9979

Correspondence: Christopher LR Barratt, Division of Systems Medicine, School of Medicine, Ninewells Hospital and Medical School, University of Dundee, Dundee, DD1 9SY, UK. c.barratt@dundee.ac.uk 
Gumerova, De Jonge and Barratt - August 19th, 2021

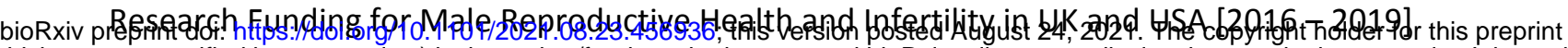
(which was not certified by peer review) is the author/funder, who has granted bioRxiv a license to display the preprint in perpetuity. It is made 26 Abstract: available under aCC-BY-NC-ND 4.0 International license.

Title: Research Funding for Male Reproductive Health and Infertility in the UK and USA [2016 - 2019]

Study question: What is the research funding for male reproductive health and infertility in the UK and US between 2016 to 2019?

Summary answer: The average funding for a research project in male reproductive health and infertility was not significantly different to that for female-based projects ( $£ 653,733$ in the UK and $\$ 779,707$ in the US). However, only $0.07 \%$ and $0.83 \%$ of government funds from NIHR (UK) and NICHD (USA) was granted for male reproductive health, respectively.

What is known already: There is a marked paucity of data on research funding for male reproductive health.

Study design, size, duration: Examined government databases over a total 4-year period from January 2016 to December 2019.

Participants/materials, setting, methods: Information on the funding provided to male-based and female-based research was collected using public accessed web-databases from the UKRI-GTR, the NIHR's Open Data Summary, and the US' NIH RePORT. Funded projects that began research activity between January 2016 to December 2019 were recorded, along with their grant and project details. Strict inclusion-exclusion criteria were followed for both UK and US data with a primary research focus of male infertility, reproductive health and disorders, and contraception development. Funding support was divided into three research groups: male-based, female-based, and not-specified research. Between the 4-year period, the UK is divided into 5 funding periods, starting from 2015/16 to $2019 / 20$, and the US is divided into 5 fiscal years, from 2016 to 2020 . 
Gumerova, De Jonge and Barratt - August 19th, 2021

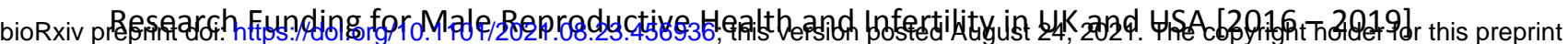
(which was not certified by peer review) is the author/funder, who has granted bioRxiv a license to display the preprint in perpetuity. It is made

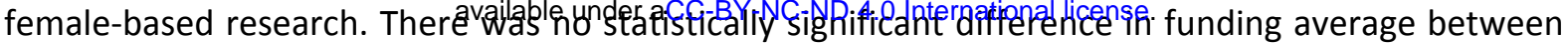
the two research groups $(P=0.56, W=392)$. The US NIH funded 76 projects totaling $\$ 59,257,746$ for male-based research and 99 projects totaling $\$ 83,272,898$ for female-based research. There was no statistically significant difference in funding average between the two groups ( $P=0.83, W=3834)$.

Limitations, reasons for caution: The findings of this study cannot be used to generalize and reflect global funding trends towards infertility and reproductive health as the data collected followed a narrow funding timeframe from government agencies and only two countries. Other funding sources such as charities, industry and major philanthropic organizations were not evaluated.

Wider implications of the findings: This is the first study examining funding granted by main government research agencies from the UK and US for male reproductive health. This study should stimulate further discussion of the challenges of tackling male infertility and reproductive health disorders and formulate appropriate investment strategies.

Study funding/competing interest(s): CLRB is Editor for RBMO and has received lecturing fees from Merck, Pharmasure, and Ferring. His laboratory is funded by Bill and Melinda Gates Foundation, CSO, Genus. No other authors declare a conflict of interest. 
Gumerova, De Jonge and Barratt - August 19th, 2021

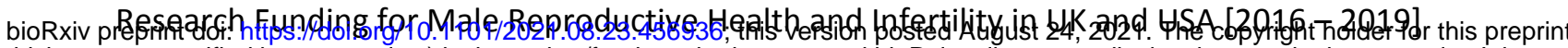
66

(which was not certified by peer review) is the author/funder, who has granted bioRxiv a license to display the preprint in perpetuity. It is made available under acfítrbdúction. International license.

67

Several recent studies have highlighted considerable research gaps in the understanding of male infertility encompassing critical areas such as basic science research, clinical diagnostics, nonMedically Assisted Reproduction (MAR) treatment options, and the impact of damage to the male genome on the health of the next generation (Barratt et al., 2017, Barratt et al., 2018, De Jonge and Barratt 2019, Barratt et al., 2021, Schlegel et al., 2021a,b). One general conclusion that can be drawn from these analyses is that significant funding is required to address the research questions (Barratt et al., 2017, Barratt et al., 2018). For any discipline, including reproductive medicine, an important aspect of assessing and formulating future funding requirements is to ascertain current funding. This knowledge can then be used to facilitate an objective needs analysis.

Surprisingly, there is a paucity of data on funding levels for male infertility and male reproductive health research (Barratt et al., 2018, Barratt et al., 2021). To date, only one study has specifically documented funding for male reproductive health research. Liao and colleagues (Liao et al., 2020) assessed funding by the National Natural Science Foundation of China (NNSFC) for male infertility and reproductive health research between 1998-2018. The authors split this 20-year period into 3 funding phases beginning from 1998. By the third phase (2010-2018), a substantial increase of funding was awarded for male reproductive health (MRH) basic research by the NNSFC. However, there was minimal detail on the exact funding values. Barratt and colleagues provided a snapshot of funding for Male Reproductive Health in several countries that suggested overall funding levels were low, but no other details were provided (Barratt et al., 2021).

In this study, we investigated government funded support of male reproductive health research. We examined research funded between January 2016 to December 2019 from the UK and US agencies. To provide context, we included funding for female-based reproductive health research and examined the proportion of research funding for reproductive health research and compared to the total research funding. 
Gumerova, De Jonge and Barratt - August 19th, 2021

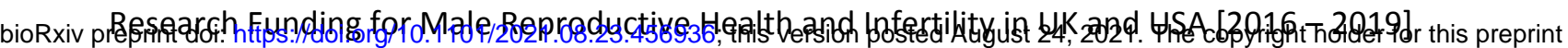
91

(which was not certified by peer review) is the author/funder, who has granted bioRxiv a license to display the preprint in perpetuity. It is made

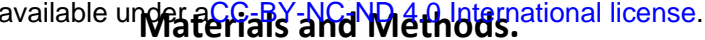

92

93

\section{Experimental Design:}

Publicly accessible UK Research and Innovation (UKRI), National Institute for Health Research (NIHR), and National Institutes of Health (NIH) funding agency databases covering awards from January 2016 to December 2019 were examined (see Supplementary Table I). Following the inclusion and exclusion criteria outlined within Supplementary Tables II and III, funding data were collected on research proposals investigating infertility and reproductive health. For simplicity, these are referred to collectively as 'infertility research'. As the primary focus of this research is on infertility, the data were divided into three main groups: male-based, female-based, and not-specified (Supplementary Table II). The first two groups covered projects whose primary aim, based on the information presented in the research abstracts, timeline summaries and/or impact statements, was male- or female-focused. "Not-specified" includes research projects that have either not specified a primary focus towards either male or female or have explicitly stated a focus on both. The process was conducted and reviewed by E.G. with C.L.R.B. Total funding for all three groups, funding over time, and comparison with overall funding for a particular agency was examined.

\section{UK Data Collection:}

Starting in April 2018, the UK research councils, Innovate UK, and Research England were combined reporting under one organization, the UKRI (UKRI, 2019). The councils, such as the Medical Research Council (MRC), Biotechnology and Biological Sciences Research Council (BBSRC), Engineering and Physical Sciences Research Council (EPSRC), and Natural Environment Research Council (NERC), independently fund research projects according to their respective visions and missions; however, from 2018/19, their annual funding expenditures were reported under the UKRI's annual reports and budgets. The UKRI's Gateway to Research (UKRI-GTR) web-database allows users to analyse information provided on taxpayer-funded research. Relevant search terms such as "male infertility" or "female reproductive health" (see Supplementary Table II) were applied with appropriate database 
Gumerova, De Jonge and Barratt - August 19th, 2021

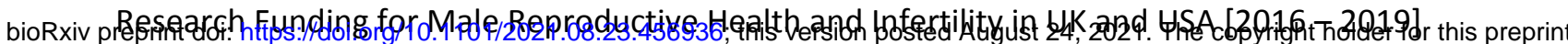
(which was not certified by peer review) is the author/funder, who has granted bioRxiv a license to display the preprint in perpetuity. It is made

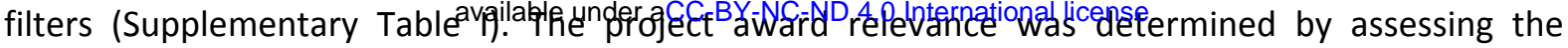
objectives in project abstracts, timeline summaries, and planned impacts. Supplementary Tables I, II and III provide the search filters and the reference criteria for inclusion/exclusion utilized for analysis. The UKRI-GTR provides the total funding amount granted to the projects within a designated period.

The Open Data Summary View dataset from the NIHR was used as it provided details on funded projects, grants, summary abstracts, and project dates. Like the UKRI data, the NIHR excel datasheet had specific search terms and filters applied to exclude irrelevant projects (Supplementary Tables I, II, and III).

The UKRI councils and NIHR report their annual expenditure and budgets for 1st April to 31st March.

Thus, the selected projects will fall under the funding period of when their research activities begin,

e.g. if a research project is started between May 20th, 2017, to March 20th, 2019, the project will be categorized under the funding period $2017 / 18$. The projects assessed would begin their investigations between January 2016 to December 2019, therefore 5 consecutive funding periods were examined (2015/16, 2016/17, 2017/18, 2018/19, and 2019/20).

\section{US Data Collection:}

The NIH has a research portfolio online operating tools site (RePORT) providing access to their research activities, such as previously funded research, actively funded research projects, and information on NIH's annual expenditures. The RePORT-Query database has similar features as the UKRI-GTR and NIHR such as providing information on project abstracts, research impact, start- and end-dates, funding grants, and type of research. The same inclusion-exclusion criteria were applied as for the UK data collection, (see Supplementary Tables I, II, and III). from October 1st to September 30th, i.e., FY2016 comprises funding activity from October 1st, 2015, to September 30th, 2016. Projects running over one calendar period are reported several times under 
Gumerova, De Jonge and Barratt - August 19th, 2021

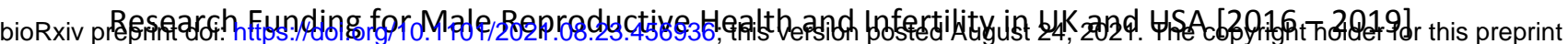
(which was not certified by peer review) is the author/funder, who has granted bioRxiv a license to display the preprint in perpetuity. It is made

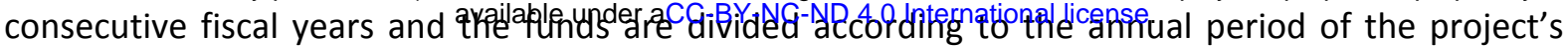

activity.

During data collection, 74 projects were found as active with incomplete funding sums as the NIH funds for the FY2021, so projects ending in FY2020 or FY2021 have provided a complete funding sum. For the active projects ending after 2021, incomplete funding data is shown. It is assumed the funding will increase in value by the time the research project ends in the future. To remain consistent with the UK data, projects granted funding are totalled as one figure and recorded under the FY the project first began research, whether they are active or completed. Thus, the US funding is referred to as "Current Total Funding". For the US, the initial data collection period ran between October 2020 to December 2020 but then restarted for a brief period in January 2021 to complete the remaining funding values for several of the active research projects.

\section{Data Analysis:}

The data were divided into the three groups and organized into the funding period or FY during which the project was first awarded. R-Studio (Version 1.3.1093) was utilized for the data analysis. Box-andwhisker plots are presented with rounded $P$-values. Kruskal-Wallis and Wilcoxon Rank Sum tests were generated to assess any statistical significance. The data were independently collected and do not assume a normal distribution, so rank-based, non-parametric tests such as the Kruskal-Wallis and Wilcoxon Rank-Sum were used. The Kruskal-Wallis test was used between more than 2 groups, with the $P$-values and Chi-Squared $\left(\chi^{2}\right)$ values provided. The Wilcoxon test was used between two groups statistically significant. 
Gumerova, De Jonge and Barratt - August 19th, 2021

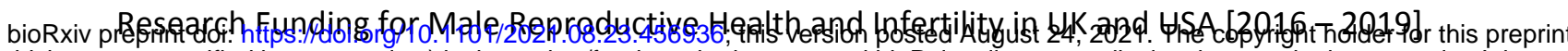
(which was not certified by peer review) is the author/funder, who has granted bioRxiv a license to display the preprint in perpetuity. It is made 164 available under aCC-RY-Nút 4.0 International license.

165

Total and Median Funding:

\section{UK Data:}

Total funding for infertility from the UK funding agencies and the summary statistics of the UK data are presented in Tables I and II. Table III details the proportion of funding by the MRC and NIHR from 2015/16 to 2018/19. Between 2016 to 2019,76 studies were awarded funding by 4 UKRI councils and the NIHR investigating infertility and reproductive health. The MRC, BBSRC, and NIHR were the top 3 awarding agencies, having funded 29, 23, and 15 projects, respectively. The UK agencies have awarded 18 projects for male-based, 40 for female-based, and 18 projects for the non-specified group (Table I). For NIHR funding, there were only 2 awards for the male group compared to 11 for female group. Figure 1 presents a distribution of funding for the three groups. There was more spread for the female group, however there was no statistically significant difference between the mean values of the 3 groups $\left(P=0.69\right.$, Kruskal-Wallis, $\left.\chi^{2}=0.72\right)$. There was no significant difference between male-based versus female-based funding $(P=0.56, W=392)$.

\section{USA Data:}

The US total funding for infertility and summary statistics are presented in Tables IV and V. The funding amounts presented in Table IV includes research grants, program grants, and fellowships and contains the respective annual spending of each NIH institute. The NIH have awarded 76 projects for malebased, 99 for female-based, and 31 projects for the non-specified group. The National Institute of Child Health and Human Development (NICHD), Environmental Health Sciences (NIEHS), and General Medical Sciences (NIGMS) have awarded the most for infertility research out of 14 institutes, funding 138,27 , and 26 projects, respectively.

The spread of funding is not largely different between the male-based and female-based groups (Figure 2), but more projects appeared to localize at the lower end of the scale for the female-based 
Gumerova, De Jonge and Barratt - August 19th, 2021

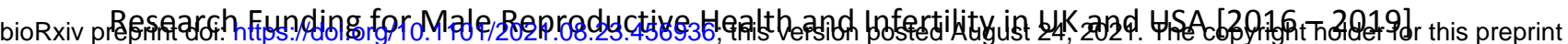
(which was not certified by peer review) is the author/funder, who has granted bioRxiv a license to display the preprint in perpetuity. It is made

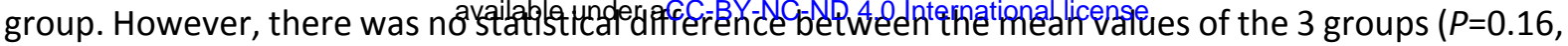

Kruskal Wallis $\left.\chi^{2}=4.1\right)$. There were no significant differences between male- and female-based research $(P=0.83, W=3834)$.

Funding over the years:

Funding over 4 consecutive years is presented in Supplementary Tables IV and V for the UK and US, respectively. The total funding, mean funding amount over the respective funding periods, and the distribution of data are presented in Supplementary Figures 1 and 2. There were no statistical significant difference in the funding over time within each of the 3 groups ( $P>0.05$, Kruskal-Wallis), for both the UK and US.

The proportion of funding allocated to male and female infertility research is presented in Table III for dedicated research specialty for Reproductive Health and Childbirth (NIHR, 2021). When examining funding allocated directly for infertility research by the MRC, the proportion of total funding peaks at $1.58 \%$ in $2016 / 17$ (Table III). For the NIHR, the largest proportion of funding allocated to infertility research was in $2019 / 20$ with $2.31 \%$ of the year's total awards. When examining total funding by the NIHR between 2015/16 and 2019/20, the proportion of funding for male-based infertility research was $0.07 \%$ and $0.79 \%$ for female-based research.

In the USA, of the $27 \mathrm{NIH}$ institutes and research centres, the NICHD is a primary funder for furthering research on human development, improvement for reproductive health, and enhancing the lives of children and young adults $(\mathrm{NIH}, 2021)$. This also encompasses research for infertility and 
Gumerova, De Jonge and Barratt - August 19th, 2021

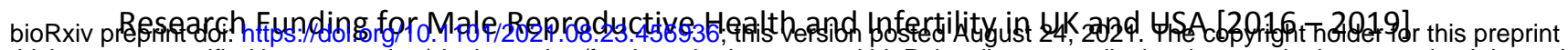
(which was not certified by peer review) is the author/funder, who has granted bioRxiv a license to display the preprint in perpetuity. It is made

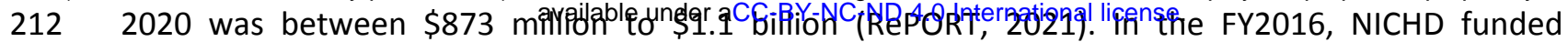

$213 \$ 1,021,132,045$ for research grants and fellowships, but only $1.63 \%$ or $\$ 16,684,751$ was for infertility

214 research (as defined by the eligibility criteria in this study; Table VI). The funding proportion for the

215 male-based research group was $0.48 \%$, which was similar to the female-based funding proportion,

$2160.51 \%$. The proportion of total funding provided by the NICHD between 2016 and 2019 that was

217 allocated to infertility research was estimated at $2.56 \%$, with male-based receiving $0.83 \%$ and female-

218 based receiving $1.32 \%$. 
Gumerova, De Jonge and Barratt - August 19th, 2021

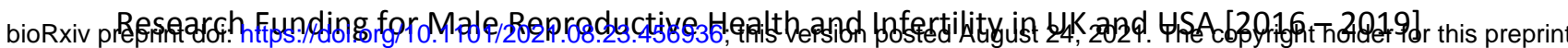
(which was not certified by peer review) is the author/funder, who has granted bioRxiv a license to display the preprint in perpetuity. It is made available under aCG Discuśssiof 4.0 International license.

221 This study provides details of UK and US government funding for male infertility and male reproductive

health covering the period 2016-2019. The information will be instructive for different stakeholders,

e.g. workers in the discipline, grant organisations, commercial companies, and policy makers. This will enable the development of evidence-based informed decisions for future funding strategies This is critical as male infertility poses a global health risk for many millions of men yet research funding is not concomitant with the prevalence or impact of the disease.

We analysed public-accessible databases for UKRI, NIHR (UK) and US (NIH) covering the period of awards from January 2016 to December 2019. The primary objective was to determine funding for male reproductive health and infertility research. To provide context, we assessed 3 groups based on the primary focus of the research in reproductive biology/medicine: male-based, female-based, and not-specified (Supplementary Table II). Information from the aims, research abstracts, timeline summaries, and/or impact statements, was used to determine if a study was included and, if so, to which group it was assigned. This is necessarily a subjective process, therefore we provide our search and entry/exclusion criteria (Supplementary Tables I, II, and III), as well as a supplementary table of the research projects' titles from the UK and US (Supplementary Tables VI and VII). Whilst incorporation of different terms may produce different answers, the results are robust. For example, the application of data extraction is consistent between countries as the inclusion/exclusion criteria were the same. We were focused on infertility and associated links to infertility and reproductive disorders. No analysis was made to assess if there is bias in funding research for female reproduction versus male reproduction. Moreover, we do not examine submission numbers, triage, rejection rates, etc. and thus prioritization of research cannot be assessed. 
Gumerova, De Jonge and Barratt - August 19th, 2021

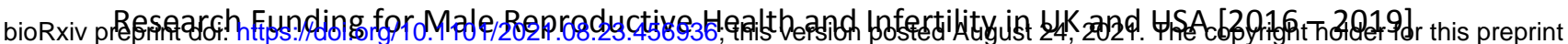
(which was not certified by peer review) is the author/funder, who has granted bioRxiv a license to display the preprint in perpetuity. It is made

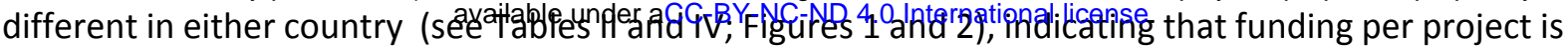
not different between male and female reproductive health.

An important question to answer is, what is the proportion of funding for reproduction/male reproductive health compared to general research funding? There are several approaches to address this question. For both the UK and USA data, one method is to examine the total funding for research by the main funding agency and compare this to the data for male- and female-based research. Reproductive health research is primarily supported by the MRC and NIHR in the UK, and by the NICHD in the USA. In the funding periods $2015 / 16$ to $2017 / 18$, the total infertility research funding by MRC ranged from $0.87 \%$ to $1.58 \%$ of the total budget (Table III). Infertility research funding from NIHR ranged from $0.08 \%$ to $2.31 \%$ ( $2015 / 16$ to $2019 / 20$, Table III). For the US, the maximum infertility research funding by the NICHD was $3.39 \%$ of its total budget (Table VI).

Another approach was to assess the proportion of funding compared between research disciplines, or research categories, in the UK and USA, respectively. Within the UK data, we specifically examined research disciplines funded by the NIHR. From the April 1 ${ }^{\text {st }}, 2011$ to present, the NIHR awarded over f216 million for Reproductive Health and Childbirth research, their 7th largest funding category. Mental Health, Cancer, and Cardiovascular Diseases were within the top 5 most funded categories (Supplementary Table VIII). NIHR awarded $f 21$ million in 2017/18 for Reproductive Health and Childbirth research (NIHR, 2021), yet surprisingly there was minimal support towards male-based research as between 2016 to 2019 only two projects were funded (Table I, Supplementary Table VI). The small number of projects in male reproductive health funded by the NIHR was unexpected as NIHR are the largest UK funders for health care and clinical research (NIHR, 2021). NIHR supported 302 studies for reproductive health with 94 of them being newly funded projects for $2019 / 20$. However, using our criteria for study inclusion we only identified 4 projects focusing on infertility over the whole period (Table I, Supplementary Table IV). While we do not know the reason for the low funding rate, 
Gumerova, De Jonge and Barratt - August 19th, 2021

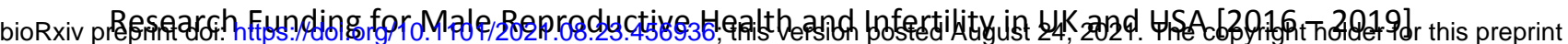
(which was not certified by peer review) is the author/funder, who has granted bioRxiv a license to display the preprint in perpetuity. It is made

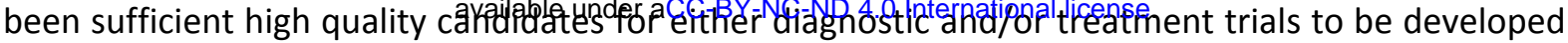

in male reproductive health (Barratt et al., 2021).

To compare different research categories for the USA data, we did not use our collected data to provide estimated funding. Instead, we used the NIH's Research Portfolio Online Reporting Tools estimates of funding for various Research Condition and Disease Categories (RCDC) (https://report.nih.gov/funding/categorical-spending\#/) and the $\mathrm{NIH}^{\prime}$ s annual research grants

\section{(https://report.nih.gov/funding/nih-budget-and-spending-data-past-fiscal-years/budget-and-}

spending). For the $\mathrm{NIH}$, the values presented for the 299 RCDCs are not mutually exclusive because a project can fall under several categories. We examined research categories similar to those at the NIHR. For NIH these included: Contraception/Reproduction, Infertility, Obesity, and Mental Health (Supplementary Table IX). By estimating the proportion of funding for these categories from the NIH's Total Research Funding, we can see those categories such as Obesity and Mental Health were highly funded in comparison to Contraception/Reproduction and Infertility.

NICHD has funded under $1 \%$ of their annual research grants for male-based research for 3 out of 4 consecutive fiscal years (Table VI). NICHD are primary funders for reproduction, infertility, and contraceptive development, therefore, it was unexpected to observe such low funding proportions. A possible factor for why our calculated funding proportion values by the NICHD are low may be due to our strict eligibility criteria during data collection. However, we applied our eligibility and exclusion criteria equally across all funding agencies, for the UK and US.

Two pertinent points arise from our study. Firstly, compared to the prevalence of the disease where 1:7 couples are infertile (Boivin et al., 2007, NICE, 2013), the proportion of research funding for male reproductive health is small (less than $1 \%$, see Tables III and VI) compared to other diseases in the UK and US (Supplementary Table IX). This is surprising especially because MAR is a multi-billion-dollar global industry. Secondly, although the number of awards for female-based research is generally 
Gumerova, De Jonge and Barratt - August 19th, 2021

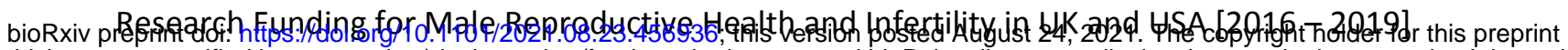
(which was not certified by peer review) is the author/funder, who has granted bioRxiv a license to display the preprint in perpetuity. It is made

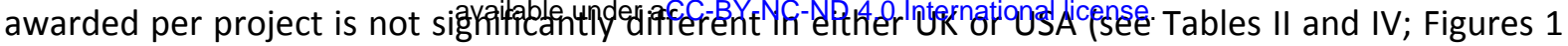

and 2). Whilst there are many challenges in comparing research funding between disciplines, the present findings directly imply a significant gap between impact of disease prevalence and research male reproductive health.

There are several limitations to our study. Firstly, these findings cannot be generalized to reflect funding trends towards infertility and reproductive health worldwide. The data were collected from governmental agencies of two countries and over a narrow funding period. Further, the funding priorities of UK and US governmental agencies may not be a 'good fit model' for the funding priorities

Wellcome Trust, industry, Bill and Melinda Gates Foundation, and other major philanthropic organisations. As the UKRI, NIHR, and NIH are governmental agencies, their prioritization to providing fellowships, research grants, program centre grants, and others may not be similar to other charities and international organizations. Detailed analysis of funding from these other agencies would be instructive and assist in a more comprehensive analysis. Future work should include data from more countries, NGO's and include longer funding timeframes to accurately estimate total funding supporting for male infertility and male reproductive health and for more comprehensive assessment of funding trends.

In summary, we present recent government funding for male-based infertility and reproductive health, and by extension, funding towards female-based research. The information provided in this 
Gumerova, De Jonge and Barratt - August 19th, 2021

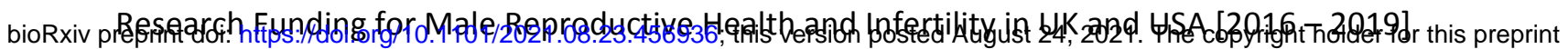
(which was not certified by peer review) is the author/funder, who has granted bioRxiv a license to display the preprint in perpetuity. It is made

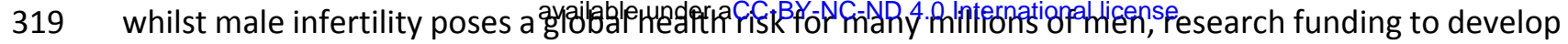

320 better diagnostic tools and treatment regimens is not on par. The data analysis presented herein

321 should stimulate discussions for a strategic development of male reproductive health care 322 investments. 
Gumerova, De Jonge and Barratt - August 19th, 2021

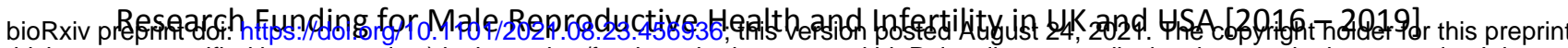
(which was not certified by peer review) is the author/funder, who has granted bioRxiv a license to display the preprint in perpetuity. It is made 325 Acknowledgements:

The initial concept for this work was based on discussions as part of the ESHRE MRHI Working Group.

We are grateful to ESHRE for providing ground-breaking funding and for their continued support. We are grateful to Dr Stephen J. Publicover of University of Birmingham for providing critical feedback on the manuscript.

Conflicts of Interests:

CLRB is Editor for RBMO and has received lecturing fees (2019) from Merck, Pharmasure, and Ferring. His laboratory is funded by Bill and Melinda Gates Foundation, CSO, Genus. No other authors declare a conflict of interest.

Authors Roles:

The experimental design, primary data collection, and initial statistical analysis was performed by EG as part of her undergraduate BSc honours research project. The initial draft of the manuscript was written by EG and $C B$ following discussions with CJD. All authors contributed to writing and editing the manuscript and approving the final version.

Funding:

No specific funding was provided for data collection and/or analysis for this study. Whilst undertaking this work EG was a BSc Biomedical Sciences honours student at University of Dundee, School of Life Sciences, Dundee. ESHRE have provided funds to facilitate meetings and interactions of the MRHI Working Group.

Data Availability Statements: 
Gumerova, De Jonge and Barratt - August 19th, 2021

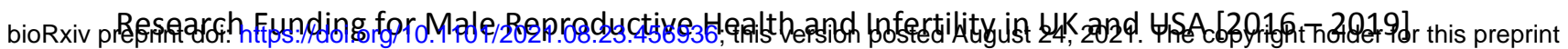
(which was not certified by peer review) is the author/funder, who has granted bioRxiv a license to display the preprint in perpetuity. It is made

References: available under aCC-BY-NC-ND 4.0 International license.

Barratt CLR, Bjorndahl L, De Jonge CJ, Lamb DJ, Osorio Martini F, McLachlan R, Oates RD, van der Poel S, St John B, Sigman M, Sokol R, Tournaye H. The diagnosis of male infertility: an analysis of the evidence to support the development of global WHO guidance-challenges and future research opportunities. Hum Reprod Update 2017; 23: 660-680.

Barratt CLR, De Jonge CJ, Sharpe RM. 'Man Up': the importance and strategy for placing male reproductive health centre stage in the political and research agenda. Hum Reprod 2018; 33: 541-545

Barratt CLR, De Jonge CJ, Anderson RA, Eisenberg ML, Garrido N, Rautakallio Hokkanen S, Krausz C, Kimmins S, O'Bryan MK, Pacey AA. A global approach to addressing the policy, research and social challenges of male reproductive health. Human Reproduction Open; Volume 2021, Issue 1

Boivin J, Bunting L, Collins JA, Nygren KG. International estimates of infertility prevalence and treatment-seeking: potential need and demand for infertility medical care. Hum Reprod 2007; 22: 1506-1512.

De Jonge $C$, Barratt CLR. The present crisis in male reproductive health: an urgent need for a political, social, and research roadmap. Andrology 2019; 7: 762-76.

Liao SJ, Xu YY, Sun RJ, Lyu QY. National natural science foundation of China leads the comprehensive development of basic research in the field of male reproductive health in China. Asian J Androl 2020; 22: $547-548 /$

National Institute for Health and Clinical Excellence. Fertility: Assessment and Treatment for People with Fertility Problems NICE Clinical Guideline, Manchester.2013

NIH. National Institutes of Health - Institutes, Centers and Office. [Internet]. 2021. Available from: https://www.nih.gov/institutes-nih/list-nih-institutes-centers-offices

NIHR. National Institute for Health Research - About Us.[Internet]. 2021; Available from: https://www.nihr.ac.uk/about-us/

NIHR. National Institute for Health Research - Reproductive Health and Childbirth.[Internet]. 2021; Available from: https://www.nihr.ac.uk/explore-nihr/specialties/reproductive-health.htm

RePORT - Research Portfolio Online Reporting Tools. Budget and Spending. [Internet]. 2021. Available from: https://report.nih.gov/funding/nih-budget-and-spending-data-past-fiscal-years/budget-andspending

Schlegel PN, Sigman M, Collura B, De Jonge CJ, Eisenberg ML, Lamb DJ, Mulhall JP, Niederberger C, Sandlow JI, Sokol RZ, Spandorfer SD, Tanrikut C, Treadwell JR, Oristaglio JT, Zini A. Diagnosis and treatment of infertility in men: AUA/ASRM guideline part I. Fertil Steril 2021a; 115: 54-61.

Schlegel PN, Sigman M, Collura B, De Jonge C, Eisenberg ML, Lamb DJ, Mulhall JP, Niederberger C, Sandlow JI, Sokol R, Spandorfer SD, Tanrikut C, Treadwell JR, Oristaglio JT, Zini A. Diagnosis and treatment of infertility in men: AUA/ASRM guideline part II. Fertil Steril 2021b; 115: 62-69.

UKRI. UK Research and Innovation - Annual Report and Accounts 2018-2019. In Department for Business EalS (ed). 2019, pp. 144 
Gumerova, De Jonge and Barratt - August 19th, 2021

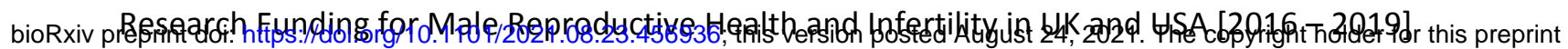
(which was not certified by peer review) is the author/funder, who has granted bioRxiv a license to display the preprint in perpetuity. It is made [dataset]* Gumerova, Eva; Devajongle under Male Reproductive Health and Infertility in the UK and USA [2016 - 2019], Dryad, Dataset, https://doi.org/10.5061/dryad.v9s4mw6wc 
Gumerova, De Jonge and Barratt - August 19th, 2021

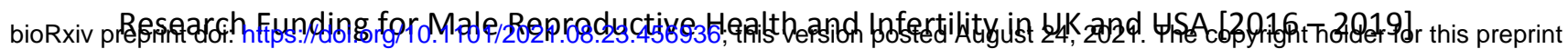
(which was not certified by peer review) is the author/funder, who has granted bioRxiv a license to display the preprint in perpetuity. It is made 390 available under aC Mánin Figures ${ }^{O}$ International license.

391

Figure 1: Box-and-whisker plot with a 95\% confidence interval (CI) of awards for UK infertility and reproductive

NIHR.

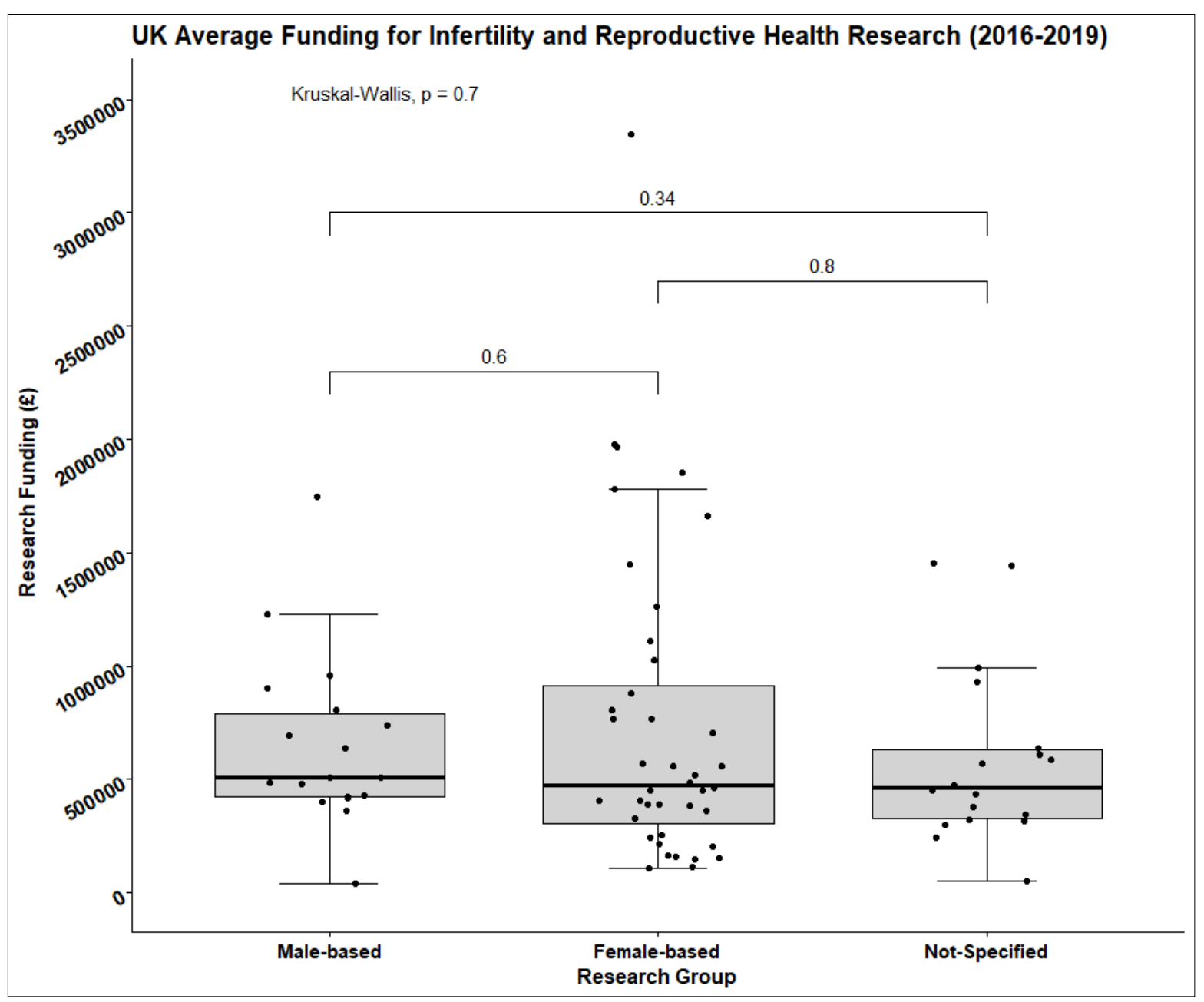


Gumerova, De Jonge and Barratt - August 19th, 2021

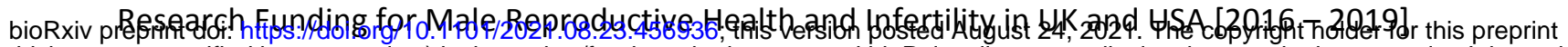
(which was not certified by peer review) is the author/funder, who has granted bioRxiv a license to display the preprint in perpetuity. It is made 398 available under aCC-BY-NC-ND 4.0 International license.

Figure 2: Box-and-whisker plot has a $95 \% \mathrm{Cl}$ of the funding collected for US infertility and reproductive health

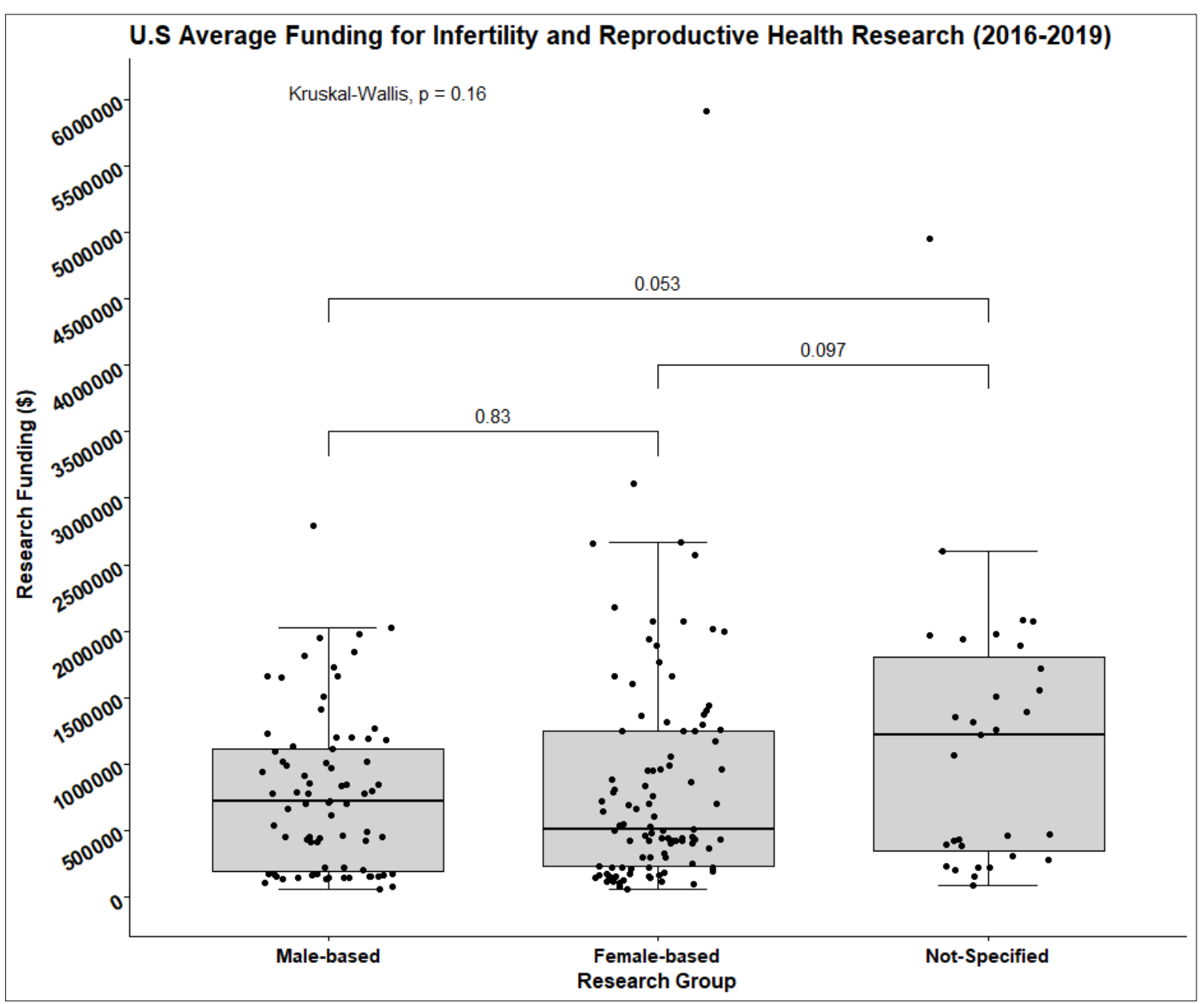


Gumerova, De Jonge and Barratt - August 19th, 2021

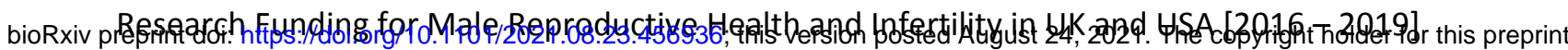
404 (which was not certified by peer review) is the author/funder, who has granted bioRxiv a license to display the preprint in perpetuity. It is made

405

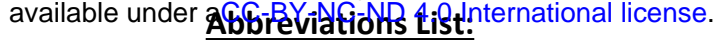

\begin{tabular}{|l|l|}
\hline \multicolumn{2}{|l|}{ Abbreviations for Funding Agencies/Institutes, Research Councils, and Databases } \\
\hline BBSRC & Biotechnology and Biological Sciences Research Council \\
\hline EPSRC & Engineering and Physical Sciences Research Council \\
\hline HRCS & Health Research Classification System \\
\hline MRC & Medical Research Council \\
\hline NCCIH & National Centre for Complementary and Integrative Health \\
\hline NERC & Natural Environment Research Council \\
\hline NIA & National Institute of Aging \\
\hline NIAAA & National Institute on Alcohol Abuse and Alcoholism \\
\hline NIAID & National Institute of Allergy and Infectious Diseases \\
\hline NIBIB & National Institute of Biomedical Imaging and Bioengineering \\
\hline NICHD & National Institute of Child Health and Health Development \\
\hline NIDDK & National Institute of Diabetes and Digestive and Kidney Diseases \\
\hline NIEHS & National Institutes of Environmental Health Sciences \\
\hline NIGMS & National Institute of General Medical Sciences \\
\hline NHBLI & National Heart, Blood, Lung Institute \\
\hline NIH & National Institutes of Health \\
\hline NIHR & National Institute of Health and Research \\
\hline NINR & National Institute of Nursing Research \\
\hline NIOSH & National Institute for Occupational Safety and Health \\
\hline OD & NIH's Offices of the Director \\
\hline RCDC & Research, Conditions and Diseases Categories \\
\hline RePORT & Research Portfolio Online Reporting Tools \\
\hline UKRI & UK Research and Innovation \\
\hline UKRI-GTR & UK Research and Innovation - Gateway to Research \\
\hline
\end{tabular}

406

407 
bioRxiv preprint doi: https://doi.org/10.1101/2021.08.23.456936; this version posted August 24, 2021. The copyright holder for this preprint (which was not certified by peer review) is the author/funder, who has granted bioRxiv a license to display the preprint in perpetuity. It is made available under aGmäln Täblês International license.

Research Funding for Male Infertility and Male Reproductive Health in the UK and USA [2016 - 2019]

Authors and Affiliations:

Eva Gumerova

Christopher J De Jonge

Christopher LR Barratt

Eva Gumerova:

School of Life Sciences, University of Dundee, Dundee, UK. egumerova@dundee.ac.uk ORCID: 00000002-2585-3769

Christopher L.R. Barratt*:

Division of Systems Medicine, School of Medicine, Ninewells Hospital and Medical School, University of Dundee, Dundee, DD19SY, UK. c.barratt@dundee.ac.uk ORCID: 0000-0003-0062-9979

Christopher J. De Jonge:

University of Minnesota Medical Center, Department of Urology, University of Minnesota. 606 24th Avenue South, Suite 525, Minneapolis, MN 55454, USA. ORCID: 0000-0002-4083-5833

Correspondence: Christopher LR Barratt, Division of Systems Medicine, School of Medicine, Ninewells Hospital and Medical School, University of Dundee, Dundee, DD19SY, UK. c.barratt@dundee.ac.uk 
bioRxiv preprint doi: https://doi.org/10.1101/2021.08.23.456936; this version posted August 24, 2021. The copyright holder for this preprint (which was not certified by peer review) is the author/funder, who has granted bioRxiv a license to display the preprint in perpetuity. It is made available under aGGAIN NABRLES International license.

\begin{tabular}{|c|c|c|c|c|c|}
\hline \multirow[b]{2}{*}{$\begin{array}{l}\text { Funding } \\
\text { Period }\end{array}$} & \multirow[b]{2}{*}{$\begin{array}{l}\text { Funding } \\
\text { Agency }\end{array}$} & \multirow{2}{*}{$\begin{array}{c}\text { Total Funding for } \\
\text { Research Grants and } \\
\text { Fellowships } \\
(\mathbf{( 0 0 0 ) *}\end{array}$} & \multicolumn{3}{|c|}{ Research Groups } \\
\hline & & & $\begin{array}{l}\text { Male-based }(f) \\
{[N]}\end{array}$ & $\begin{array}{l}\text { Female-based }(\mathrm{f}) \\
{[\mathrm{N}]}\end{array}$ & $\begin{array}{c}\text { Not-Specified }(f) \\
{[N]}\end{array}$ \\
\hline \multirow{4}{*}{$2015 / 16$} & BBSRC & 330,473 & 0 & 0 & 0 \\
\hline & EPSRC & 691,280 & 0 & 0 & 0 \\
\hline & MRC & 487,157 & $\begin{array}{c}1,748,922 \\
{[1]}\end{array}$ & $\begin{array}{c}3,346,448 \\
{[1]}\end{array}$ & 0 \\
\hline & NIHR & 268,000 & 0 & $\begin{array}{c}214,625 \\
{[1]}\end{array}$ & 0 \\
\hline \multirow{5}{*}{$2016 / 17$} & BBSRC & 331,062 & $\begin{array}{c}1,328,455 \\
{[3]}\end{array}$ & 0 & $\begin{array}{c}695,839 \\
{[2]} \\
\end{array}$ \\
\hline & EPSRC & 733,188 & $\begin{array}{c}958,032 \\
{[1]}\end{array}$ & 0 & 0 \\
\hline & MRC & 341,630 & $\begin{array}{c}676,826 \\
{[2]}\end{array}$ & $\begin{array}{c}3,259,734 \\
{[6]}\end{array}$ & $\begin{array}{c}1,444,459 \\
{[1]}\end{array}$ \\
\hline & NERC & 190,519 & 0 & 0 & $\begin{array}{c}51,390 \\
{[1]}\end{array}$ \\
\hline & NIHR & 263,300 & 0 & $\begin{array}{c}1,027,318 \\
{[1]}\end{array}$ & 0 \\
\hline \multirow{5}{*}{$2017 / 18$} & BBSRC & 348,808 & $\begin{array}{c}359,758 \\
{[1]}\end{array}$ & $\begin{array}{c}359,772 \\
{[1]}\end{array}$ & $\begin{array}{c}1,042,358 \\
{[2]}\end{array}$ \\
\hline & EPSRC & 844,134 & $\begin{array}{c}694,461 \\
{[1]}\end{array}$ & 0 & $\begin{array}{c}244,593 \\
{[1]}\end{array}$ \\
\hline & MRC & 325,164 & $\begin{array}{c}903,026 \\
{[1]}\end{array}$ & $\begin{array}{c}1,287,441 \\
{[2]}\end{array}$ & $\begin{array}{c}636,510 \\
{[1]}\end{array}$ \\
\hline & NERC & 220,618 & 0 & 0 & 0 \\
\hline & NIHR & 274,000 & $\begin{array}{c}477,541 \\
{[1]}\end{array}$ & $\begin{array}{c}2,140,292 \\
{[3]}\end{array}$ & 0 \\
\hline \multirow{4}{*}{$2018 / 19$} & BBSRC & \multirow{3}{*}{$1,439,505 * *$} & $\begin{array}{c}934,840 \\
{[2]}\end{array}$ & $\begin{array}{c}1,719,275 \\
{[4]}\end{array}$ & $\begin{array}{c}2,276,094 \\
{[4]}\end{array}$ \\
\hline & $\begin{array}{c}\text { EPSRC/ } \\
\text { UKRI }\end{array}$ & & 0 & $\begin{array}{c}252,693 \\
{[1]}\end{array}$ & 0 \\
\hline & MRC & & 0 & $\begin{array}{c}5,535,724 \\
{[7]}\end{array}$ & $\begin{array}{c}437,695 \\
{[1]}\end{array}$ \\
\hline & NIHR & 269,600 & $\begin{array}{c}507,909 \\
{[1]}\end{array}$ & $\begin{array}{c}165,595 \\
{[1]}\end{array}$ & $\begin{array}{c}1,333,890 \\
{[2]}\end{array}$ \\
\hline \multirow{5}{*}{$2019 / 20$} & BBSRC & \multirow{4}{*}{$1,401,130 * *$} & $\begin{array}{c}1,139,195 \\
{[2]}\end{array}$ & $\begin{array}{c}779,165 \\
{[2]}\end{array}$ & 0 \\
\hline & $\begin{array}{c}\text { EPSRC/ } \\
\text { UKRI }\end{array}$ & & $\begin{array}{c}1,230,976 \\
{[1]}\end{array}$ & $\begin{array}{c}766,542 \\
{[1]}\end{array}$ & $\begin{array}{c}1,455,327 \\
{[1]}\end{array}$ \\
\hline & MRC & & $\begin{array}{c}807,249 \\
{[1]}\end{array}$ & $\begin{array}{c}1,564,917 \\
{[4]}\end{array}$ & $\begin{array}{c}323,754 \\
{[1]}\end{array}$ \\
\hline & NERC & & 0 & 0 & $\begin{array}{c}611,514 \\
{[1]}\end{array}$ \\
\hline & NIHR & 321,200 & 0 & $\begin{array}{c}7,431,405 \\
{[5]}\end{array}$ & 0 \\
\hline $\begin{array}{l}\text { otal Fundin } \\
\text { E) }\end{array}$ & & & $\begin{array}{c}11,767,190 \\
{[18]}\end{array}$ & $\begin{array}{c}29,850,945 \\
{[40]}\end{array}$ & $\begin{array}{c}10,553,423 \\
{[18]}\end{array}$ \\
\hline
\end{tabular}

Table I Values collected are rounded to the nearest $\mathrm{f}$ Sterling pound. [N] refers to the number of projects awarded. *Total funding for research grants and fellowships (in millions) by the respective UKRI councils and NIHR were determined by consulting their public annual budgeting reports; ${ }^{* *}$ As of the funding period 2018/19 and onwards, all UKRI councils report their annual expenditures as one, therefore the annual expenditure for research and innovation were obtained from the UKRI's annual reports. 
bioRxiv preprint doi: https://doi.org/10.1101/2021.08.23.456936; this version posted August 24, 2021. The copyright holder for this preprint (which was not certified by peer review) is the author/funder, who has granted bioRxiv a license to display the preprint in perpetuity. It is made Table II: Summary of the UK Awarded Research by the UKRI and NIHR

\begin{tabular}{llll}
\hline & \multicolumn{2}{c}{ Research Group } \\
\cline { 2 - 4 } & $\begin{array}{l}\text { Male-based } \\
{[\mathrm{N}=18]}\end{array}$ & $\begin{array}{l}\text { Female-based } \\
{[\mathrm{N}=40]}\end{array}$ & $\begin{array}{l}\text { Not-Specified } \\
{[\mathrm{N}=18]}\end{array}$ \\
\hline Total (f) & $11,767,190$ & $29,850,945$ & $10,553,423$ \\
\hline Mean & 653,733 & 746,274 & 586,301 \\
(SD) & $(384,131)$ & $(690,065)$ & $(387,951)$ \\
\hline Median & 507,197 & 476,163 & 463,394 \\
(IQR) & $(423,630-789,793)$ & $(308,001-914,762)$ & $(328,457-630,261)$ \\
\hline
\end{tabular}

Table II: All values are rounded to the nearest $f$ Sterling pound. SD, standard deviation of the data group; IQR, interquartile range which encompasses $50 \%$ of the data group. 
bioRxiv preprint doi: https://doi.org/10.1101/2021.08.23.456936; this version posted August 24, 2021. The copyright holder for this preprint (which was not certified by peer review) is the author/funder, who has granted bioRxiv a license to display the preprint in perpetuity. It is made

\begin{tabular}{|c|c|c|c|c|c|c|}
\hline $\begin{array}{l}\text { Funding } \\
\text { Period }\end{array}$ & $\begin{array}{c}\text { UK } \\
\text { Agency }\end{array}$ & $\begin{array}{l}\text { Total Research } \\
\text { Grants and } \\
\text { Fellowships } \\
\text { (f) }\end{array}$ & $\begin{array}{l}\text { Total Funding } \\
\text { Proportion for } \\
\text { Infertility } \\
\text { Research } \\
\text { (\%) }\end{array}$ & $\begin{array}{l}\text { Male-based } \\
\text { Funding } \\
\text { Proportion } \\
\text { (\%) }\end{array}$ & $\begin{array}{c}\text { Female-based } \\
\text { Funding } \\
\text { Proportion } \\
\text { (\%) }\end{array}$ & $\begin{array}{l}\text { Not-Specified } \\
\text { Funding } \\
\text { Proportion } \\
\text { (\%) }\end{array}$ \\
\hline \multirow{2}{*}{$2015 / 16$} & MRC & $487,157,000$ & 1.05 & 0.36 & 0.69 & 0 \\
\hline & NIHR & $268,000,000$ & 0.08 & 0 & 0.08 & 0 \\
\hline \multirow{2}{*}{$2016 / 17$} & MRC & $341,630,000$ & 1.58 & 0.2 & 0.95 & 0.42 \\
\hline & NIHR & $263,300,000$ & 0.39 & 0 & 0.39 & 0 \\
\hline \multirow{2}{*}{$2017 / 18$} & MRC & $325,164,000$ & 0.87 & 0.28 & 0.4 & 0.19 \\
\hline & NIHR & $274,000,000$ & 0.96 & 0.17 & 0.78 & 0 \\
\hline $2018 / 19$ & NIHR & $269,600,000$ & 0.74 & 0.19 & 0.06 & 0.49 \\
\hline $2019 / 20$ & NIHR & $321,200,000$ & 2.31 & 0 & 2.31 & 0 \\
\hline Total & NIHR & $1,396,100,000$ & 0.87 & 0.07 & 0.79 & 0.1 \\
\hline
\end{tabular}

Table III: The estimated proportion of funding for the UK was calculated using the data collected from Table 1. The proportions are rounded two 2 decimal points. The total research grants and fellowship values were obtained from the respective UK agency's annual reports and budgets. The MRC total research grants and fellowships from 2018/19-2019/20 were excluded as they are part of the UKRI and report their annual expenditures under one with other research councils, therefore the exact sum for research grants and fellowships for MRC was not available. The total funding proportion is only looking at NIHR funding from 2015/16 to 2019/20. 
bioRxiv preprint doi: https://doi.org/10.1101/2021.08.23.456936; this version posted August 24, 2021. The copyright holder for this preprint (which was not certified by peer review) is the author/funder, who has granted bioRxiv a license to display the preprint in perpetuity. It is made Table IV: Current Total Funding for Infertility Research Awarded by the NIH's funding institutes and the respective fiscal years.

\begin{tabular}{|c|c|c|c|c|c|}
\hline \multirow[b]{2}{*}{$\begin{array}{l}\text { Fiscal } \\
\text { Year }\end{array}$} & \multirow{2}{*}{$\begin{array}{l}\text { NIH's Funding } \\
\text { Institutes \& } \\
\text { Centres }\end{array}$} & \multirow{2}{*}{$\begin{array}{l}\text { Total Funding for } \\
\text { Research Grants } \\
(\$)^{*}\end{array}$} & \multicolumn{3}{|c|}{ Research Groups } \\
\hline & & & $\begin{array}{c}\text { Male-based (\$) } \\
{[\mathrm{N}]}\end{array}$ & $\begin{array}{l}\text { Female-based (\$) } \\
{[\mathrm{N}]}\end{array}$ & $\begin{array}{c}\text { Not-Specified (\$) } \\
{[N]}\end{array}$ \\
\hline \multirow{6}{*}{2016} & $\mathrm{NCClH}$ & $107,447,348$ & 0 & $\begin{array}{c}1,439,100 \\
{[1]}\end{array}$ & 0 \\
\hline & NIAID & $2,983,260,567$ & 0 & $\begin{array}{c}2,219,320 \\
{[2]}\end{array}$ & 0 \\
\hline & $\mathrm{NICHD}$ & $1,021,132,045$ & $\begin{array}{c}4,927,677 \\
{[7]}\end{array}$ & $\begin{array}{c}5,183,197 \\
{[8]}\end{array}$ & $\begin{array}{c}6,573,877 \\
{[4]}\end{array}$ \\
\hline & NIDDK & $1,580,485,601$ & 0 & $\begin{array}{c}95,610 \\
{[1]}\end{array}$ & 0 \\
\hline & NIEHS & $407,288,463$ & $\begin{array}{c}1,784,198 \\
{[4]}\end{array}$ & $\begin{array}{c}3,890,638 \\
{[6]}\end{array}$ & $\begin{array}{c}233,712 \\
{[1]}\end{array}$ \\
\hline & NIGMS & $2,231,411,724$ & $\begin{array}{c}4,822,891 \\
{[3]}\end{array}$ & 0 & $\begin{array}{c}8,085,074 \\
{[5]}\end{array}$ \\
\hline \multirow{6}{*}{2017} & NHBLI & $2,463,498,743$ & 0 & $\begin{array}{c}2,568,489 \\
{[1]}\end{array}$ & 0 \\
\hline & NIA & $1,708,012,380$ & $\begin{array}{c}536,946 \\
{[1]}\end{array}$ & 0 & 0 \\
\hline & NIAAA & $342,212,488$ & 0 & 0 & $\begin{array}{c}398,788 \\
{[1]}\end{array}$ \\
\hline & $\mathrm{NICHD}$ & $967,265,488$ & $\begin{array}{c}12,430,159 \\
{[15]}\end{array}$ & $\begin{array}{c}13,078,769 \\
{[14]}\end{array}$ & $\begin{array}{c}7,325,909 \\
{[5]}\end{array}$ \\
\hline & NIEHS & $1,638,513,361$ & $\begin{array}{c}1,841,716 \\
{[1]}\end{array}$ & $\begin{array}{c}2,076,388 \\
{[1]}\end{array}$ & $\begin{array}{c}1,829,137 \\
{[2]}\end{array}$ \\
\hline & NIGMS & $411,526,579$ & $\begin{array}{c}2,831,714 \\
{[3]}\end{array}$ & $\begin{array}{c}3,105,261 \\
{[1]}\end{array}$ & $\begin{array}{c}2,776,900 \\
{[2]}\end{array}$ \\
\hline \multirow{7}{*}{2018} & NIA & $2,053,235,620$ & 0 & $\begin{array}{c}118,485 \\
{[1]}\end{array}$ & 0 \\
\hline & NIAID & $3,339,613,240$ & 0 & $\begin{array}{c}868,774 \\
{[1]}\end{array}$ & 0 \\
\hline & $\mathrm{NICHD}$ & $1,028,491,002$ & $\begin{array}{c}8,755,795 \\
{[13]}\end{array}$ & $\begin{array}{c}17,441,843 \\
{[19]}\end{array}$ & $\begin{array}{c}2,396,625 \\
{[5]}\end{array}$ \\
\hline & NIDDK & $1,613,382,619$ & 0 & 0 & $\begin{array}{c}85,224 \\
{[1]}\end{array}$ \\
\hline & NIEHS & $458,275,648$ & $\begin{array}{c}4,412,912 \\
{[3]}\end{array}$ & $\begin{array}{c}3,443,045 \\
{[4]}\end{array}$ & $\begin{array}{c}1,943,533 \\
{[1]}\end{array}$ \\
\hline & NIGMS & $2,506,055,218$ & $\begin{array}{c}2,537,197 \\
{[3]}\end{array}$ & $\begin{array}{c}3,231,516 \\
{[3]}\end{array}$ & $\begin{array}{c}1,971,230 \\
{[1]}\end{array}$ \\
\hline & $\mathrm{NIOSH}$ & Unavailable** & $\begin{array}{c}169,500 \\
{[1]}\end{array}$ & 0 & 0 \\
\hline \multirow{7}{*}{2019} & NIAID & $3,496,548,418$ & 0 & $\begin{array}{c}2,668,689 \\
{[1]}\end{array}$ & 0 \\
\hline & NIBIB & $381,987,928$ & 0 & 0 & $\begin{array}{c}1,259,032 \\
{[1]}\end{array}$ \\
\hline & $\mathrm{NICHD}$ & $1,099,202,749$ & $\begin{array}{c}8,395,362 \\
{[16]}\end{array}$ & $\begin{array}{c}18,668,208 \\
{[31]}\end{array}$ & 0 \\
\hline & NIEHS & $454,787,252$ & $\begin{array}{c}1,095,907 \\
{[1]}\end{array}$ & $\begin{array}{c}1,792,109 \\
{[2]}\end{array}$ & 0 \\
\hline & NIGMS & $2,558,317,976$ & $\begin{array}{c}2,364,252 \\
{[3]}\end{array}$ & $\begin{array}{c}888,154 \\
{[1]}\end{array}$ & $\begin{array}{c}1,064,618 \\
{[1]}\end{array}$ \\
\hline & NINR & $129,862,737$ & 0 & $\begin{array}{c}495,303 \\
{[1]}\end{array}$ & 0 \\
\hline & $O D$ & $594,535,751$ & $\begin{array}{c}1,505,963 \\
{[1]}\end{array}$ & 0 & 0 \\
\hline \multirow[t]{2}{*}{2020} & $\mathrm{NICHD}$ & $1,133,572,974$ & 0 & 0 & $\begin{array}{c}218,250 \\
{[1]}\end{array}$ \\
\hline & NIEHS & $466,088,243$ & 845,557 & 0 & 0 \\
\hline
\end{tabular}


bioRxiv preprint doi: https://doi.org/10.1101/2021.08.23.456936; this version posted August 24, 2021. The copyright holder for this preprint (which was not certified by peer review) is the author/funder, who has granted bioRxiv a license to display the preprint in perpetuity. It is made available under aCC-BY-NC T 4 P 4.0 International license.

\begin{tabular}{lccc}
\hline Current Total Funding (\$) & $59,257,746$ & $83,272,898$ & $36,161,909$ \\
\hline
\end{tabular}

Table IV: Values collected are rounded to the nearest US $\$$ dollar. [N] refers to the number of projects awarded. From the start of data collection to the analysis, 7 projects changed their statuses from active to completed, making 138 projects out of 206 as active running. 67 of the 138 projects do not provide complete funding sums by the $\mathrm{NIH}$, therefore, the funds were totalled up to their most recent awarding FY. *The values for the annual spending of research grants by the NIH (in millions) was found in the NIH's RePORT Funding site: The Research Grants: Awards and Total Funding, by type and Institute/Centre. ${ }^{* *}$ The values were not made available by the $\mathrm{NIH}$. 
bioRxiv preprint doi: https://doi.org/10.1101/2021.08.23.456936; this version posted August 24, 2021. The copyright holder for this preprint (which was not certified by peer review) is the author/funder, who has granted bioRxiv a license to display the preprint in perpetuity. It is made Table V: Summary Statistics of the US Awarded Research by the NIH

\begin{tabular}{lccc}
\hline & & Research Group & \\
\cline { 2 - 4 } & $\begin{array}{c}\text { Male-based } \\
{[\mathrm{N}=76]}\end{array}$ & $\begin{array}{c}\text { Female-based } \\
{[\mathrm{N}=99]}\end{array}$ & $\begin{array}{c}\text { Not-Specified } \\
{[\mathrm{N}=31]}\end{array}$ \\
\hline Current Total (\$) & $59,257,746$ & $83,272,898$ & $36,161,909$ \\
\hline Mean & 779,707 & 841,140 & $1,194,687$ \\
(SD) & $(594,203)$ & $(862,707)$ & $(1,046,679)$ \\
\hline Median & 718,541 & 511,781 & $1,223,600$ \\
(IQR) & $(193,449-1,117,370)$ & $(227,847-1,246,408)$ & $(388,397-1,891,778)$ \\
\hline
\end{tabular}

Table V: All values presented are rounded to the nearest US dollar and produced using RStudio. 
bioRxiv preprint doi: https://doi.org/10.1101/2021.08.23.456936; this version posted August 24, 2021. The copyright holder for this preprint (which was not certified by peer review) is the author/funder, who has granted bioRxiv a license to display the preprint in perpetuity. It is made

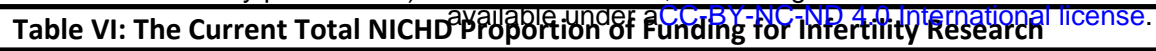

\begin{tabular}{ccccccc}
\hline Fiscal Year & $\begin{array}{c}\text { NIH } \\
\text { Agency }\end{array}$ & $\begin{array}{c}\text { Total Research } \\
\text { Grants and } \\
\text { Fellowships } \\
\mathbf{( \$ )}\end{array}$ & $\begin{array}{c}\text { Total Funding } \\
\text { Proportion for } \\
\text { Infertility } \\
\text { Research } \\
\mathbf{( \% )}\end{array}$ & $\begin{array}{c}\text { Male-based } \\
\text { Funding } \\
\text { Proportion } \\
(\%)\end{array}$ & $\begin{array}{c}\text { Female-based } \\
\text { Funding } \\
\text { Proportion } \\
\text { (\%) }\end{array}$ & $\begin{array}{c}\text { Not-Specified } \\
\text { Funding } \\
\text { Proportion (\%) }\end{array}$ \\
\hline $\mathbf{2 0 1 6}$ & NICHD & $1,021,132,045$ & 1.63 & 0.48 & 0.51 & 0.64 \\
\hline $\mathbf{2 0 1 7}$ & NICHD & $967,265,488$ & 3.39 & 1.29 & 1.35 & 0.75 \\
\hline $\mathbf{2 0 1 8}$ & NICHD & $1,028,491,002$ & 2.78 & 0.85 & 1.7 & 0.23 \\
\hline $\mathbf{2 0 1 9}$ & NICHD & $1,099,202,749$ & 2.46 & 0.76 & 1.7 & 0 \\
\hline Total & NICHD & $4,116,091,284$ & 2.56 & 0.83 & 1.32 & 0.4 \\
\hline
\end{tabular}

Table VI: The estimated proportion of funding for the US was calculated using the data collected from Table 4. FY2020 was excluded as only one project was awarded between $1^{\text {st }}$ October to $31^{\text {st }}$ December 2019 and would be unreflective of the funding proportion for this year. The total proportion looks at the total funding provided by the NICHD for infertility research from 2016 to 2019 and the total research funding granted by the NICHD. The annual research grants and fellowship values were obtained from the NIH's RePORT Budget and Spending site: The Research Grants: Awards and Total Funding, by type and Institute/Centre. 
bioRxiv preprint doi: https://doi.org/10.1101/2021.08.23.456936; this version posted August 24, 2021. The copyright holder for this preprint (which was not certified by peer review) is the author/funder, who has granted bioRxiv a license to display the preprint in perpetuity. It is made

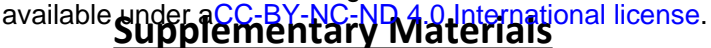

Research Funding for Male Reproductive Health and Infertility in the UK and USA [2016 - 2019]

Authors and Affiliations:

Eva Gumerova

Christopher J. De Jonge

Christopher L.R. Barratt

Eva Gumerova:

School of Life Sciences, University of Dundee, Dundee, UK. egumerova@dundee.ac.uk ORCID: 00000002-2585-3769

Christopher J. De Jonge:

University of Minnesota Medical Center, Department of Urology, University of Minnesota. 606 24th Avenue South, Suite 525, Minneapolis, MN 55454, USA. ORCID: 0000-0002-4083-5833

Christopher L.R. Barratt*:

Division of Systems Medicine, School of Medicine, Ninewells Hospital and Medical School, University of Dundee, Dundee, DD19SY, UK. c.barratt@dundee.ac.uk ORCID: 0000-0003-0062-9979

Correspondence: Christopher LR Barratt, Division of Systems Medicine, School of Medicine, Ninewells Hospital and Medical School, University of Dundee, Dundee, DD19SY, UK. c.barratt@dundee.ac.uk 
bioRxiv preprint doi: https://doi.org/10.1101/2021.08.23.456936; this version posted August 24, 2021. The copyright holder for this preprint (which was not certified by peer review) is the author/funder, who has granted bioRxiv a license to display the preprint in perpetuity. It is made Supplementary Tables: available under aCC-BY-NC-ND 4.0 International license.

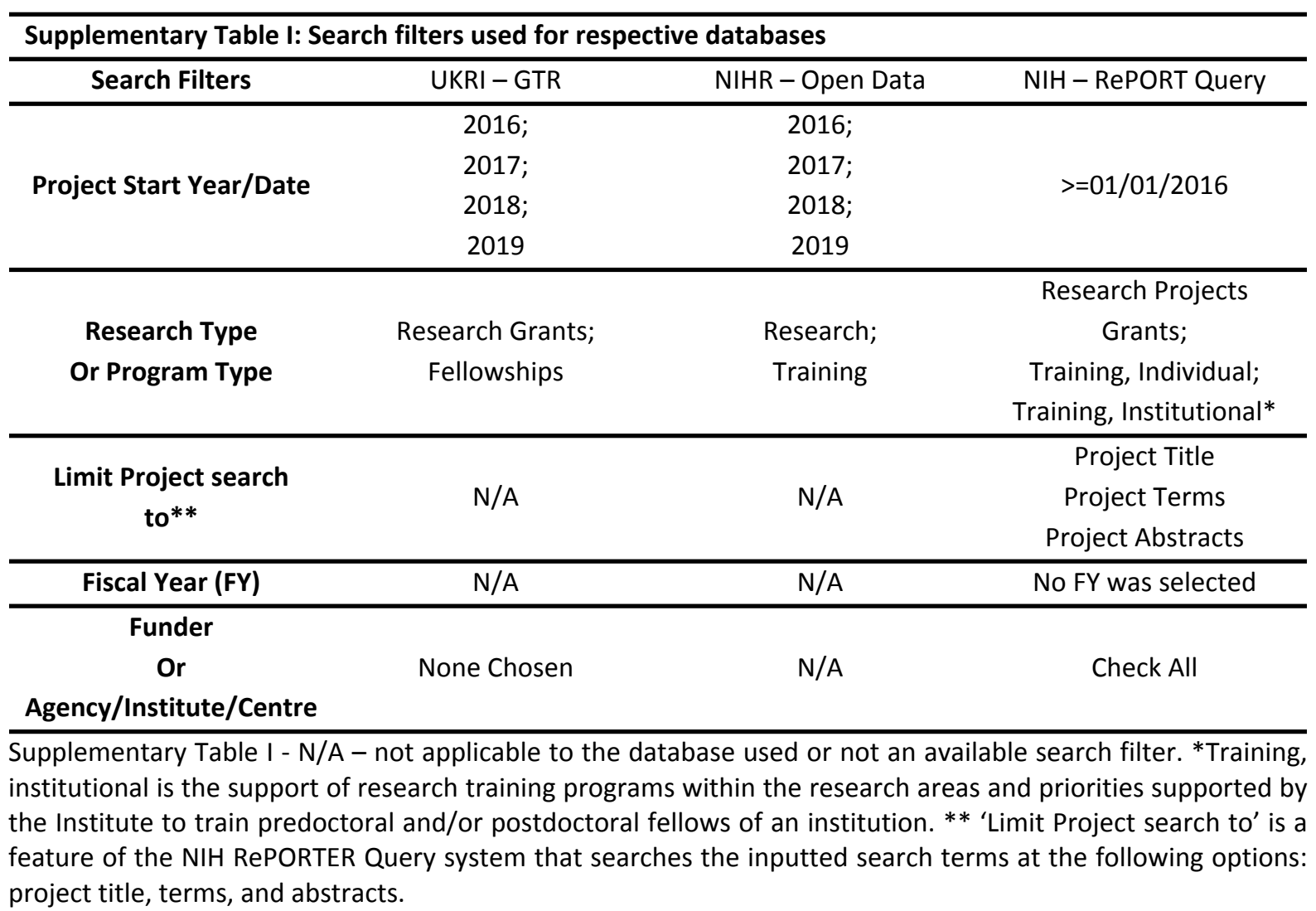


bioRxiv preprint doi: https://doi.org/10.1101/2021.08.23.456936; this version posted August 24, 2021. The copyright holder for this preprint (which was not certified by peer review) is the author/funder, who has granted bioRxiv a license to display the preprint in perpetuity. It is made avallabie under aCC-BY-NC-ND 4.0 International IIcense.

Supplementary Table II: Inclusion criteria for type of projects included into the data collection.

\begin{tabular}{lll}
\hline Male-focused infertility research & Female-focused infertility research & Not-specified infertility research \\
\hline Spermatogenesis research & Oogenesis research & Gametogenesis and infertility \\
\hline $\begin{array}{l}\text { Sperm maturation, motility, and } \\
\text { quality analysis research }\end{array}$ & $\begin{array}{l}\text { Menstruation/menstrual cycle } \\
\text { abnormalities }\end{array}$ & EDCs impacting general fertility \\
\hline $\begin{array}{l}\text { Sperm dysfunction/disorders } \\
\text { research }\end{array}$ & $\begin{array}{l}\text { Uterine and Ovarian disorders } \\
\text { (e.g., Endometriosis, Polycystic } \\
\text { Ovarian Syndrome, and Uterine } \\
\text { Fibroids) }\end{array}$ & $\begin{array}{l}\text { Underpinning the aetiology of } \\
\text { infertility (not specifying the focus } \\
\text { group) }\end{array}$ \\
$\begin{array}{l}\text { Testicular and Prostate health } \\
\text { (not cancer) research }\end{array}$ & $\begin{array}{l}\text { Female contraception research } \\
\text { development }\end{array}$ & $\begin{array}{l}\text { Contraception development in } \\
\text { conjunction with HIV/STI } \\
\text { prevention }\end{array}$ \\
\hline
\end{tabular}

$\begin{array}{ll}\text { Male contraception research } & \text { Maternal factors associated with } \\ \text { development } & \text { ART outcomes }\end{array}$

Studies using animal and insect models to further the understanding of human infertility and contraception development

\begin{tabular}{lll}
\hline $\begin{array}{l}\text { Paternal factors associated with } \\
\text { ART outcomes }\end{array}$ & $\begin{array}{l}\text { EDCs association with female } \\
\text { infertility }\end{array}$ & Hormonal dysregulation \\
\hline $\begin{array}{l}\text { Paternal association with fetus } \\
\text { health/development (i.e., male } \\
\text { infertility affecting fetus } \\
\text { health/development) }\end{array}$ & $\begin{array}{l}\text { Underpinning the aetiology of } \\
\text { female infertility }\end{array}$ & $\begin{array}{l}\text { Cell/embryonic development } \\
\text { dysregulation giving rise to } \\
\text { infertility }\end{array}$ \\
\hline $\begin{array}{l}\text { EDCs giving rise to male infertility } \\
\text { female infertility }\end{array}$ & $\begin{array}{l}\text { Hormonal dysregulation and } \\
\text { fnale infertility }\end{array}$ \\
\hline $\begin{array}{l}\text { Hormonal dysregulation and } \\
\text { male infertility }\end{array}$ & \\
$\begin{array}{l}\text { Supplementary Table II - The inclusion criteria for the 3-research groups after examining abstracts, research } \\
\text { impacts and public health relevance statements. Under each heading are the topics or field of research of } \\
\text { reproductive health and infertility research. }\end{array}$
\end{tabular}


bioRxiv preprint doi: https://doi.org/10.1101/2021.08.23.456936; this version posted August 24, 2021. The copyright holder for this preprint (which was not certified by peer review) is the author/funder, who has granted bioRxiv a license to display the preprint in perpetuity. It is made avallable under aCC-BY-NC-TV 4.0 International IIcense.

Supplementary Table III: Type of projects that would be excluded from the data collection if the following were indicated as the primary research focus detailed in their abstracts and impacts, and example of few exceptions to include.

\begin{tabular}{ll}
\hline Primary Research Focus & Reasons for Exclusion \\
\hline $\begin{array}{l}\text { Research focusing on } \\
\text { reproductive cancers (e.g., } \\
\text { ovarian, prostate, testicular, } \\
\text { uterine...) or other cancers }\end{array}$ & $\begin{array}{l}\text { People who have cancers and are } \\
\text { ndergaing cancer treatments can } \\
\text { away from focusing on infertility } \\
\text { funding }\end{array}$ \\
\hline $\begin{array}{l}\text { Research focusing on STIs } \\
\text { (e.g., Chlamydia trachomatis } \\
\text { or Gonorrhea) }\end{array}$ & $\begin{array}{l}\text { STIs are known to affect human } \\
\text { fertility, but are usually funded under } \\
\text { the category of infectious diseases } \\
\text { rather than reproduction and } \\
\text { infertility }\end{array}$ \\
\hline $\begin{array}{l}\text { Research focusing on HIV } \\
\text { and/or AIDs }\end{array}$ & $\begin{array}{l}\text { fertility, but are usually funded under } \\
\text { the category of infectious diseases } \\
\text { and impact the immune system }\end{array}$ \\
\hline
\end{tabular}

Exceptions to include

If the project is investigating a concern that affected human fertility in addition to potentially causing cancers, they would be included.

A study focusing on STIs would be included only if it is contraceptive development in conjunction to STI prevention

Pregnancy/gestation; pregnancy health.

Placental development

Childbirth and Labor.

Research focusing on fetus health or development

Research focusing on
miscarriages

These areas were not included as comparison was primarily aimed at examining male infertility. Work on pregnancy and fetus are more tangential to work on infertility research and creates a wider scope.
A study researching HIV or AIDs would be included only if it is contraceptive development in conjunction to HIV/AIDs prevention research would be included if it were investigating a paternal contribution to implantation and clinical pregnancy outcomes

A study focusing on this area of research would be included if it were investigating a paternal or maternal contribution to the fetus' health, development, or future reproductive health, with or without the usage of ART.

A study focusing on miscarriages would be included if it were investigating an association between miscarriages and paternal or maternal infertility, with or without the usage of ART.

Research focusing on the
sociological, policy or
economic studies for
infertility, or a public These research areas stray away from research focusing primarily on human
intervention program study infertility and reproductive health.
Research focusing on animal,
insect or plant infertility that
are not used as model for
human infertility research

Supplementary Table III - Type of projects that would be excluded from the data collection if the following were indicated as the primary research focus detailed in their abstracts and impacts, and few exceptions to include them. 
bioRxiv preprint doi: https://doi.org/10.1101/2021.08.23.456936; this version posted August 24, 2021. The copyright holder for this preprint (which was not certified by peer review) is the author/funder, who has granted bioRxiv a license to display the preprint in perpetuity. It is made available under aCC-BY-NC-ND 4.0 International license.

Supplementary Table IV: UK funding awarded across the funding periods from January 2016 to December 2019

\begin{tabular}{|c|c|c|c|}
\hline \multirow[b]{2}{*}{ Funding Period } & \multicolumn{3}{|c|}{ Research Groups } \\
\hline & $\begin{array}{l}\text { Male-based }(\mathrm{f}) \\
\text { [mean] }\end{array}$ & $\begin{array}{l}\text { Female-based }(f) \\
\text { [mean] }\end{array}$ & $\begin{array}{l}\text { Not-Specified }(\mathrm{f}) \\
\text { [mean] }\end{array}$ \\
\hline $2015 / 16$ & $1,748,922^{*}$ & $\begin{array}{l}3,561,073 \\
{[1,780,534]}\end{array}$ & 0 \\
\hline 2016/17 & $\begin{array}{l}2,963,313 \\
{[522,539]}\end{array}$ & $\begin{array}{l}4,287,052 \\
{[562,710]}\end{array}$ & $\begin{array}{l}2,191,688 \\
{[547,922]}\end{array}$ \\
\hline $2017 / 18$ & $\begin{array}{l}2,434,786 \\
{[580,108]}\end{array}$ & $\begin{array}{l}3,787,505 \\
{[631,251]}\end{array}$ & $\begin{array}{l}1,923,461 \\
{[480,865]}\end{array}$ \\
\hline 2018/19 & $\begin{array}{l}1,442,749 \\
{[480,917]}\end{array}$ & $\begin{array}{l}7,673,287 \\
{[590,253]}\end{array}$ & $\begin{array}{l}4,047,679 \\
{[578,240]}\end{array}$ \\
\hline $2019 / 20$ & $\begin{array}{l}3,177,420 \\
{[794,355]}\end{array}$ & $\begin{array}{l}10,542,029 \\
{[878,502]}\end{array}$ & $\begin{array}{l}2,390,595 \\
{[796,865]}\end{array}$ \\
\hline Total & $11,767,190$ & $29,850,945$ & $10,553,423$ \\
\hline
\end{tabular}

Supplementary Table IV - The UK funding across the 5 consecutive funding periods awarded between January 2016 to December 2019. The values are rounded to the nearest Sterling pound. ${ }^{*}$ Value belongs to a single project awarded, thus, no mean was produced. 
bioRxiv preprint doi: https://doi.org/10.1101/2021.08.23.456936; this version posted August 24, 2021. The copyright holder for this preprint (which was not certified by peer review) is the author/funder, who has granted bioRxiv a license to display the preprint in perpetuity. It is made avallable under aCC-BY-NC-ND 4.0 International IIcense.

Supplementary Table V: US Current Funding across the 5 fiscal years from January 2016 to December 2019

\begin{tabular}{|c|c|c|c|}
\hline \multirow[b]{2}{*}{ Fiscal Year } & \multicolumn{3}{|c|}{ Research Groups } \\
\hline & $\begin{array}{l}\text { Male-based (\$) } \\
\text { [mean] }\end{array}$ & $\begin{array}{l}\text { Female-based (\$) } \\
\text { [mean] }\end{array}$ & $\begin{array}{l}\text { Not-Specified (\$) } \\
\text { [mean] }\end{array}$ \\
\hline 2016 & $\begin{array}{l}11,534,766 \\
{[823,912]}\end{array}$ & $\begin{array}{l}12,827,865 \\
{[712,659]}\end{array}$ & $\begin{array}{l}14,892,663 \\
{[1,489,266]}\end{array}$ \\
\hline 2017 & $\begin{array}{l}17,640,535 \\
{[882,027]}\end{array}$ & $\begin{array}{l}20,828,907 \\
{[1,225,230]}\end{array}$ & $\begin{array}{l}12,330,734 \\
{[1,233,073]}\end{array}$ \\
\hline 2018 & $\begin{array}{l}15,875,404 \\
{[793,770]}\end{array}$ & $\begin{array}{l}25,103,663 \\
{[896,559]}\end{array}$ & $\begin{array}{l}6,396,612 \\
{[799,574]}\end{array}$ \\
\hline 2019 & $\begin{array}{l}13,361,484 \\
{[636,261]}\end{array}$ & $\begin{array}{l}24,512,463 \\
{[680,902]}\end{array}$ & $\begin{array}{l}2,323,650 \\
{[1,161,825]}\end{array}$ \\
\hline $2020 *$ & 845,557 & 0 & 218,250 \\
\hline Current Total & $59,257,746$ & $83,272,898$ & $36,161,909$ \\
\hline
\end{tabular}

Supplementary Table V - The US current funding for projects awarded funding beginning between January 2016 to December 2019. The values are rounded to the nearest US dollar. *For 2020, male-based and not-specified groups were each awarded 1 project since the beginning of the FY (October $1^{\text {st }}$ to December $31^{\text {st }}, 2019$ ), thus, no mean or median was produced. 
bioRxiv preprint doi: https://doi.org/10.1101/2021.08.23.456936; this version posted August 24, 2021. The copyright holder for this preprint (which was not certified by peer review) is the author/funder, who has granted bioRxiv a license to display the preprint in perpetuity. It is made Supplementary Table VI - Research Project titles from UK Funding Agencies

\section{Research} Group

\begin{tabular}{|c|c|c|}
\hline Female-based & PB-PG-0815-20009 & $\begin{array}{l}\text { A mixed methods evaluation of online provision of oral } \\
\text { contraceptives to measure: validity of self-reported biometric } \\
\text { data; essential information transfer and user experience of self- } \\
\text { measurement and submission of biometric data. }\end{array}$ \\
\hline Not-Specified & $\mathrm{BB} / \mathrm{S} 001255 / 1$ & $\begin{array}{l}\text { A novel mechanism underlying GnRH pulse generation by KNDy } \\
\text { neurones }\end{array}$ \\
\hline Not-Specified & $\mathrm{BB} / \mathrm{S} 000550 / 1$ & $\begin{array}{l}\text { A novel mechanism underlying GnRH pulse generation by KNDy } \\
\text { neurones }\end{array}$ \\
\hline Female-based & $15 / 113 / 01$ & $\begin{array}{l}\text { A randomised controlled trial to determine the effectiveness of } \\
\text { bridging from emergency to regular contraception: The 'Bridge- } \\
\text { it' study }\end{array}$ \\
\hline Female-based & II-LB-0715-20003 & $\begin{array}{l}\text { A trial of egg recovery rates for IVF using a collection chamber } \\
\text { that provides environmental control: Eggcell Trial. }\end{array}$ \\
\hline Female-based & MR/N024524/1 & $\begin{array}{l}\text { Androgens and women's health: developing new therapies to } \\
\text { treat endometrial disorders }\end{array}$ \\
\hline Male-based & MR/N002970/1 & $\begin{array}{l}\text { Androgens: unlocking the key drivers of male health and } \\
\text { wellbeing }\end{array}$ \\
\hline Female-based & $\mathrm{EP} / \mathrm{R} 041407 / 1$ & $\begin{array}{l}\text { Born Slippy: A Tribological Discourse on Hysterosalpingography } \\
\text { as a Therapeutic Treatment for Infertile Women }\end{array}$ \\
\hline Male-based & $\mathrm{BB} / \mathrm{S} 000801 / 1$ & $\begin{array}{l}\text { Building a molecular machine: analysis of co-chaperones for } \\
\text { assembly of ciliary dynein motor complexes }\end{array}$ \\
\hline Not-Specified & BB/P022065/1 & $\begin{array}{l}\text { Can histone code-like 'switches' govern the multi-functionality of } \\
\text { RNA-binding proteins? }\end{array}$ \\
\hline Female-based & MR/N023692/1 & $\begin{array}{l}\text { Can norethisterone enanthate (NET-EN) reduce the risk of } \\
\text { recurrent bacterial vaginosis in women at high risk for HIV } \\
\text { infection? }\end{array}$ \\
\hline Female-based & $\mathrm{MR} / \mathrm{S} 036350 / 1$ & $\begin{array}{l}\text { Cell atlas of the human female reproductive system across the } \\
\text { lifespan }\end{array}$ \\
\hline Female-based & $17 / 60 / 22$ & Chronic Endometritis and Recurrent Miscarriage - The CERM trial \\
\hline Female-based & PB-PG-0817-20046 & $\begin{array}{l}\text { Chronic endometritis and unexplained recurrent miscarriage: the } \\
\text { role of the endometrial microbiome. }\end{array}$ \\
\hline Female-based & MR/N011147/1 & $\begin{array}{l}\text { Community pharmacist provision of contraception services for } \\
\text { women receiving opiate substitution treatment }\end{array}$ \\
\hline Female-based & BB/P003435/1 & $\begin{array}{l}\text { Co-ordinated regulation of ovarian follicle assembly by Activin A } \\
\text { and FoxL2 }\end{array}$ \\
\hline Female-based & PB-PG-0317-20018 & $\begin{array}{l}\text { CRESCENDO Creating a Clinical Prediction Model to predict } \\
\text { Surgical Success in Endometriosis }\end{array}$ \\
\hline Not-Specified & $\mathrm{MR} / \mathrm{S} 023712 / 1$ & $\begin{array}{l}\text { Crowdsourcing with adolescents in Senegal to address social } \\
\text { norms limiting their access to sexual and reproductive health } \\
\text { services }\end{array}$ \\
\hline Not-Specified & $\mathrm{BB} / \mathrm{N} 006933 / 1$ & Cytoplasmic dynein and KASH5: partners in fertility \\
\hline Female-based & $\mathrm{BB} / \mathrm{R} 015961 / 1$ & $\begin{array}{l}\text { Decoding the role of follicle stimulating hormone in ovarian } \\
\text { ageing }\end{array}$ \\
\hline Female-based & $\mathrm{BB} / \mathrm{R} 015961 / 2$ & $\begin{array}{l}\text { Decoding the role of follicle stimulating hormone in ovarian } \\
\text { ageing }\end{array}$ \\
\hline Male-based & $\mathrm{BB} / \mathrm{R} 003556 / 1$ & $\begin{array}{l}\text { Defining the impact of paternal nutrition on fetal growth } \\
\text { regulation }\end{array}$ \\
\hline Not-Specified & $\mathrm{EP} / \mathrm{R} 041814 / 1$ & $\begin{array}{l}\text { Engineering Novel Imaging Technologies for Reproductive } \\
\text { Health: Transforming IVF outcomes }\end{array}$ \\
\hline Not-Specified & NE/P010911/1 & Environmental determinants of IVF treatment \\
\hline Female-based & MR/S000437/1 & Epigenome patterning in oocytes and its legacies in the embryo \\
\hline
\end{tabular}

\section{Research Study Title}

A mixed methods evaluation of online provision of oral measurement and submission of biometric data. neurones neurones bridging from emergency to regular contraception: The 'Bridgeit' study

A trial of egg recovery rates for IVF using a collection chamber that provides environmental control: Eggcell Trial. treat endometrial disorders wellbeing as a Therapeutic Treatment for Infertile Women Building a molecular machine: analysis of co-chaperones for assembly of ciliary dynein motor complexes RNA-binding proteins? recurrent bacterial vaginosis in women at high risk for HIV Cell atlas of the human female reproductive system across the Chronic endometritis and unexplained recurrent miscarriage: the role of the endometrial microbiome. women receiving opiate substitution treatment and FoxL2 Surgical Success in Endometriosis ageing ageing regulation

Engineering Novel Imaging Technologies for Reproductive Environmental determinants of IVF treatment Epigenome patterning in oocytes and its legacies in the embryo 
bioRxiv preprint doi: https://doi.org/10.1101/2021.08.23.456936; this version posted August 24, 2021. The copyright holder for this preprint (which was not certified by peer review) is the author/funder, who has granted bioRxiv a license to display the preprint in perpetuity. It is made

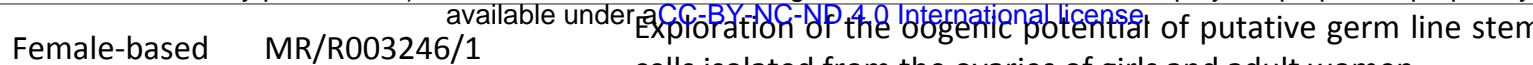

cells isolated from the ovaries of girls and adult women

Male-based BB/N009886/1 FSTL3: A Crucial Regulator of Sertoli Cell Proliferation

Male-based BB/S007407/1 Function and structure of specialised ribosomes in the testis

Female-based MR/S025235/1 Gonadotropin action in the polycystic ovary

Female-based MR/S037608/1 Harnessing cross-country administrative data to evaluate health inequalities-MatCHNet

Male-based $\quad B B / N 007026 / 1$ How does pituitary androgen signalling support lifelong health

\begin{tabular}{ll} 
Male-based & $\mathrm{MR} / \mathrm{P009948/1}$ \\
\hline Female-based & $\mathrm{BB} / \mathrm{R} 015635 / 1$ \\
\hline
\end{tabular}
and wellbeing? An integrated transgenic and systems biology approach Human germline in vitro models for development and the epigenetic program

\begin{tabular}{|c|c|c|}
\hline Female-based & $\mathrm{MR} / \mathrm{S} 002456 / 1$ & $\begin{array}{l}\text { Identifying disease promoting macrophages and tissue-identity } \\
\text { in endometriosis }\end{array}$ \\
\hline Female-based & $\mathrm{MR} / \mathrm{S} 002456 / 2$ & $\begin{array}{l}\text { Identifying disease promoting macrophages and tissue-identity } \\
\text { in endometriosis }\end{array}$ \\
\hline Male-based & BB/P006612/1 & $\begin{array}{l}\text { Identifying the functions of a family of nuclear RNA binding } \\
\text { proteins that switch expression between somatic and meiotic } \\
\text { cells }\end{array}$ \\
\hline Male-based & MR/P02419X/1 & $\begin{array}{l}\text { IMPC: Importance of PABPs in mammalian reproduction and } \\
\text { physiology }\end{array}$ \\
\hline Female-based & MR/P011454/1 & $\begin{array}{l}\text { Improving adolescent access to contraception and safe abortion } \\
\text { in sub-Saharan Africa: health system pathways }\end{array}$ \\
\hline Not-Specified & CS-2018-18-ST2-002 & $\begin{array}{l}\text { Improving the evaluation and treatment of patients with } \\
\text { reproductive disorders using kisspeptin }\end{array}$ \\
\hline Not-Specified & $\mathrm{BB} / \mathrm{R} 002703 / 1$ & Interrogating the potential of mouse primordial germ cells in vivo \\
\hline Female-based & II-LB-0715-20002 & $\begin{array}{l}\text { Intra-Uterine SENSing using a battery-less, wireless intrauterine } \\
\text { platform (U-SENSE) }\end{array}$ \\
\hline Not-Specified & $\begin{array}{l}\text { MC_EX_MR/S015930/ } \\
1\end{array}$ & $\begin{array}{l}\text { Investigating retrotransposon-driven gene expression } \\
\text { programmes in early development }\end{array}$ \\
\hline Female-based & $17 / 116 / 01$ & $\begin{array}{l}\text { Letrozole or Clomifene, with or without metformin, for ovulation } \\
\text { induction in women with polycystic ovary syndrome: a } 2 \times 2 \\
\text { factorial design randomised trial (The LOCl trial) }\end{array}$ \\
\hline Female-based & $15 / 143 / 01$ & $\begin{array}{l}\text { Medical treatment of heavy menstrual bleeding in primary care: } \\
\text { Long term follow up of ECLIPSE trial cohort }\end{array}$ \\
\hline Female-based & MR/P020283/1 & $\begin{array}{l}\text { Menstrual health interventions and school attendance in Uganda } \\
\text { (MENISCUs-2) }\end{array}$ \\
\hline Female-based & $\mathrm{MR} / \mathrm{P00265X/1}$ & $\begin{array}{l}\text { MICA: CB2 agonists as a novel treatment for women with } \\
\text { endometriosis-associated pain }\end{array}$ \\
\hline Male-based & $\mathrm{EP} / \mathrm{P} 013651 / 1$ & Modelling sperm-mucus interactions across scales \\
\hline Male-based & $\mathrm{MR} / \mathrm{S} 021248 / 1$ & MOLECULAR MECHANISMS OF MEIOTIC RECOMBINATION \\
\hline Not-Specified & MR/N022556/1 & $\begin{array}{l}\text { MRC Centre for Reproductive Health at the University of } \\
\text { Edinburgh }\end{array}$ \\
\hline Female-based & MR/M009238/2 & $\begin{array}{l}\text { Neuroinflammation in endometriosis: macrophages behaving } \\
\text { badly? }\end{array}$ \\
\hline Female-based & $\mathrm{MR} / \mathrm{R} 013454 / 1$ & $\begin{array}{l}\text { Novel methods for optimising health systems payment for } \\
\text { performance interventions to improve maternal and child health } \\
\text { in low-resource settings }\end{array}$ \\
\hline Male-based & BB/P001564/1 & $\begin{array}{l}\text { Nucleosome positioning and transcriptional regulation in } \\
\text { Drosophila differentiated cells }\end{array}$ \\
\hline
\end{tabular}
Identification of human-specific regulatory mechanisms in female germ cell development 
bioRxiv preprint doi: https://doi.org/10.1101/2021.08.23.456936; this version posted August 24, 2021. The copyright holder for this preprint (which was not certified by peer review) is the author/funder, who has granted bioRxiv a license to display the preprint in perpetuity. It is made

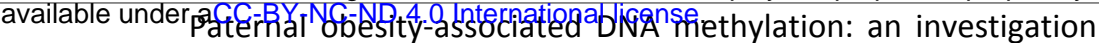

Male-based MR/P011799/1 into its reproducibility, reversibility and association with feta growth restriction

Female-based $\quad E P / S 031561 / 1$

Peptide-mimetic hydrogels as a long-acting multipurpose drug prevention

\begin{tabular}{ll} 
Female-based & MR/N006089/1 \\
\hline Male-based & MR/S017151/1 \\
\hline Female-based & MR/R022194/1 \\
\hline Male-based & EP/N021096/1 \\
\hline
\end{tabular}

Point-of-care testing and treatment of sexually transmitted infections to improve pregnancy outcomes in resource-limited, high-burden settings Protecting spermatogonial stem cells from chemotherapyinduced damage for fertility preservation in childhood cancer Puberty health interventions to improve menstrual health and School attendance among Gambian adolescents (MEGAMBO). Rapid Sperm Capture Recurrence of Endometriosis: a randomised controlled trial of

Female-based NIHR127280 clinical and cost effectiveness of Gonadotrophin Releasing Hormone Analogues with add back hormone replacement therapy versus repeat Laparoscopic surgery (REGAL trial)

\begin{tabular}{ll}
\hline Female-based & MR/R008574/1 \\
\hline Not-Specified & $16 / 95 / 01$ \\
\hline Not-Specified & BB/N018680/1 \\
\hline Not-Specified & BB/N018672/1 \\
\hline
\end{tabular}
Regulation of meiotic chromosome segregation by posttranslational modifications

REMEDY: Randomised Evaluation of Management of sExual DYsfunction Sex-determining mechanisms in the chick Sex-determining mechanisms in the chick Sex-specific disease aetiology from developmental steroid Not-Specified MR/P011535/1 insults: mechanistic understanding and biomarker development towards disease prevention.

STOP-OHSS (Shaping and Trialling Outpatient Protocols for Ovarian Hyper-Stimulation Syndrome): A feasibility study and

Female-based NIHR128137 randomised controlled trial, with internal pilot, to assess the clinical and cost-effectiveness of earlier active management of OHSS

\begin{tabular}{|c|c|c|}
\hline Not-Specified & MR/N000188/1 & Structures and mechanism of BRCA2 in meiotic recombination \\
\hline Male-based & PDF-2017-10-098 & $\begin{array}{l}\text { Targeted caloric restriction to improve sperm quality in obese } \\
\text { men with infertility }\end{array}$ \\
\hline Male-based & $17 / 68 / 01$ & $\begin{array}{l}\text { Testosterone Effects and Safety in Men with Low Testosterone } \\
\text { levels (TESTES): An evidence synthesis and economic evaluation }\end{array}$ \\
\hline Not-Specified & $\mathrm{BB} / \mathrm{S} 003681 / 1$ & $\begin{array}{l}\text { The Flux Capacitor: How mitochondria modulate metabolic flux } \\
\text { and gene expression }\end{array}$ \\
\hline Female-based & BB/T001542/1 & $\begin{array}{l}\text { Understanding hyaluronan crosslinking mechanisms in ovulation } \\
\text { and inflammation: CryoEM structural and interaction analysis of } \\
\text { HC-HA/PTX3 complexes }\end{array}$ \\
\hline Female-based & BB/T001631/1 & $\begin{array}{l}\text { Understanding hyaluronan crosslinking mechanisms in ovulation } \\
\text { and inflammation: CryoEM structural and interaction analysis of } \\
\text { HC-HA/PTX3 complexes }\end{array}$ \\
\hline Not-Specified & NE/S011188/1 & $\begin{array}{l}\text { Understanding the role of selection at the gametic level in } \\
\text { adaptation to changing environments }\end{array}$ \\
\hline Female-based & BB/S002995/1 & Unravelling the causes of declining uterine function with age \\
\hline Male-based & $\mathrm{BB} / \mathrm{S} 008039 / 1$ & $\begin{array}{l}\text { Why is the highly conserved splicing regulator protein Tra2b } \\
\text { essential for spermatogenesis? }\end{array}$ \\
\hline Female-based & MR/N015177/1 & $\begin{array}{l}\text { Women's reproductive health and its relation to diabetes and } \\
\text { cardiovascular health. }\end{array}$ \\
\hline Female-based & MR/N015177/2 & $\begin{array}{l}\text { Women's reproductive health and its relation to diabetes and } \\
\text { cardiovascular health. }\end{array}$ \\
\hline
\end{tabular}


bioRxiv preprint doi: https://doi.org/10.1101/2021.08.23.456936; this version posted August 24, 2021. The copyright holder for this preprint (which was not certified by peer review) is the author/funder, who has granted bioRxiv a license to display the preprint in perpetuity. It is made

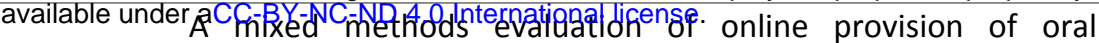

Female-based PB-PG-0815-20009 contraceptives to measure: validity of self-reported biometric data; essential information transfer and user experience of selfmeasurement and submission of biometric data.

\begin{tabular}{lll}
\hline Not-Specified & BB/S001255/1 & $\begin{array}{l}\text { A novel mechanism underlying GnRH pulse generation by KNDy } \\
\text { neurones }\end{array}$ \\
\hline Not-Specified & BB/S000550/1 & $\begin{array}{l}\text { A novel mechanism underlying GnRH pulse generation by KNDy } \\
\text { neurones }\end{array}$ \\
\hline Female-based & $\begin{array}{l}\text { A randomised controlled trial to determine the effectiveness of } \\
\text { bridging from emergency to regular contraception: The 'Bridge- } \\
\text { it' study }\end{array}$ \\
$\begin{array}{l}\text { Supplementary Table VI-Research project titles from the UKRI and NIHR (UK) funding agencies. Some projects } \\
\text { titles are repeated; however they would have separate grants awarded with different project IDs. Further } \\
\text { information on each research project can be found in the UKRI and NIHR Dataset_EG_CDJ_CLRB. }\end{array}$
\end{tabular}


bioRxiv preprint doi: https://doi.org/10.1101/2021.08.23.456936; this version posted August 24, 2021. The copyright holder for this preprint (which was not certified by peer review) is the author/funder, who has granted bioRxiv a license to display the preprint in perpetuity. It is made

\begin{tabular}{|c|c|c|}
\hline $\begin{array}{l}\text { Research } \\
\text { Group }\end{array}$ & Project Reference & Research Study Title \\
\hline Female-based & 1R01HD100318-01 & $\begin{array}{l}\text { 3/4: Pre-IVF Treatment with GNRH Antagonist in Women with } \\
\text { Endometriosis - A prospective double blind placebo controlled } \\
\text { trial (PREGNANT) }\end{array}$ \\
\hline Male-based & 1R03HD087429-01A1 & $\begin{array}{l}\text { A genome-wide drosophila RNA1 screen for regulators of } \\
\text { centrosome reduction }\end{array}$ \\
\hline Male-based & 1R21HD092828-01 & A home-based, rapid, sensitive semen analyser \\
\hline Female-based & 1R01ES026964-01 & $\begin{array}{l}\text { A longitudinal study of endocrine disrupter mixtures and } \\
\text { reproductive aging }\end{array}$ \\
\hline Female-based & 1R21HD090242-01 & $\begin{array}{l}\text { A mouse model to demonstrate the impact of myometrial FSHR } \\
\text { on fertility }\end{array}$ \\
\hline Female-based & 1R01ES028923-01A1 & $\begin{array}{l}\text { A preconception cohort study of air pollution, fertility, and } \\
\text { miscarriage }\end{array}$ \\
\hline Not-Specified & 1F32HD095620-01 & $\begin{array}{l}\text { A role for hypothalamic melanocortin } 3 \text { receptors in integrating } \\
\text { energy state with reproductive physiology }\end{array}$ \\
\hline Male-based & 5R01HD091068-03 & A system for culturing mammalian spermatogonial cells \\
\hline Male-based & 1R01HD095841-01 & Accumulation, storage, and release of sperm in the oviduct \\
\hline Male-based & 1R01HD098039-01 & ALDH1A/A2 inhibitors for male contraception \\
\hline Male-based & 1R61HD099743-01 & $\begin{array}{l}\text { Allosteric cdk2 inhibitor discovery and development for male } \\
\text { contraception }\end{array}$ \\
\hline Female-based & 1F32HD090854-01A1 & $\begin{array}{l}\text { An ovary-on-a-chip for understanding early folliculogenesis and } \\
\text { reproductive toxicology in a large mammalian model }\end{array}$ \\
\hline Female-based & 1U54HD096957-01 & $\begin{array}{l}\text { Antibody-based contraceptive MPTS: preclinical and clinical } \\
\text { research }\end{array}$ \\
\hline Male-based & 1F31HD089693-01A1 & $\begin{array}{l}\text { Assessing microenvironment and endothelial cell instruction of } \\
\text { testis function }\end{array}$ \\
\hline Female-based & 1R01HD096266-01 & Biological role of uterine glands in pregnancy \\
\hline Not-Specified & $\begin{array}{l}2752015000021-4- \\
27500002-1\end{array}$ & $\begin{array}{l}\text { Biological testing facility - maintenance of existing non-human } \\
\text { primate colony }\end{array}$ \\
\hline Female-based & 1R01AT008824-01A1 & $\begin{array}{l}\text { Botanicals derived progestins and their impact on women's } \\
\text { health }\end{array}$ \\
\hline Male-based & 1R01HD096745-01A1 & Calcium signaling nanodomains in sperm motility and fertility \\
\hline Not-Specified & 1R44HD097063-01 & $\begin{array}{l}\text { Capsule-intravaginal ring for sustained release of antibodies for } \\
\text { non-hormonal contraception and vaginal protection against HIV }\end{array}$ \\
\hline Not-Specified & 1R35GM118066-01 & Causes and consequences of aneuploidy \\
\hline Female-based & 1R01HD092550-01 & $\begin{array}{l}\text { Causes and consequences of mitochondrial dysfunction in } \\
\text { oocytes and cumulus cells }\end{array}$ \\
\hline Female-based & $\begin{array}{l}275201300019 \mid-0- \\
27500005-1\end{array}$ & $\begin{array}{l}\text { CCTN-pharmacokinetic/pharmacodynamic evaluation of } \\
\text { levonorgestrel butanoate for female contraception }\end{array}$ \\
\hline Male-based & 1R15HD096759-01A1 & $\begin{array}{l}\text { Cell-type specific inactivation of sumoylation during mouse } \\
\text { spermatogenesis }\end{array}$ \\
\hline Male-based & 1F32HD086986-01 & $\begin{array}{l}\text { Chromatin dynamics, transcriptional activators and repressors } \\
\text { in transition from proliferating progenitors to terminal } \\
\text { differentiation during adult stem cell differentiation }\end{array}$ \\
\hline Female-based & 1R01GM123048-01A1 & $\begin{array}{l}\text { Chromatin expulsion by the DNA replication licensing factor } \\
\text { orc4 during asymmetric cell division in meiosis and } \\
\text { differentiation }\end{array}$ \\
\hline Male-based & 1R01GM123643-01 & Circumventing the blood-testis barrier \\
\hline Female-based & 1F30HD085652-01A1 & $\begin{array}{l}\text { Compartmental adrenomedullin signalling in the uterus during } \\
\text { implantation }\end{array}$ \\
\hline
\end{tabular}


bioRxiv preprint doi: https://doi.org/10.1101/2021.08.23.456936; this version posted August 24, 2021. The copyright holder for this preprint (which was not certified by peer review) is the author/funder, who has granted bioRxiv a license to display the preprint in perpetuity. It is made

\begin{tabular}{|c|c|c|}
\hline Male-based & $\begin{array}{r}\text { available u } \\
\text { 1R21HD090371-01A1 }\end{array}$ & 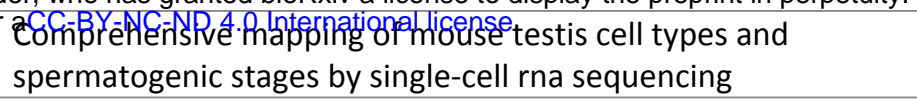 \\
\hline Male-based & 1R01GM127379-01A1 & Control of spermatogonial stem cell formation \\
\hline Female-based & 1R61HD099750-01 & Copper intravaginal contraception \\
\hline Not-Specified & 1R21HD098621-01A1 & $\begin{array}{l}\text { Correction of endocrine disruptor-induced transgenerational } \\
\text { epimutations by CRISPR-DCAS9 }\end{array}$ \\
\hline Male-based & $\begin{array}{l}\text { 1P01HD087157-01A1 } \\
8120\end{array}$ & $\begin{array}{l}\text { Crispr/cas9 and Small Molecules for Targeting Sperm Function } \\
\text { and Fertilization }\end{array}$ \\
\hline Male-based & 1R01GM123512-01A1 & Deciphering Pachytene piRNA Function \\
\hline Male-based & 1R03HD093990-01A1 & $\begin{array}{l}\text { Defining Mechanisms of Pp1 Phosphatase Specificity and } \\
\text { Function Required for Male Fertility }\end{array}$ \\
\hline Female-based & 1F31HD097830-01 & $\begin{array}{l}\text { Defining the Neurophysiologic Mechanisms Engaged by } \\
\text { Estradiol Feedback in Regulating Reproductive Neuroendocrine } \\
\text { Function }\end{array}$ \\
\hline Not-Specified & 1R15HD084253-01A1 & $\begin{array}{l}\text { Defining the Novel Role for the Rna Binding Protein Etr-1 in } \\
\text { C.elegans Gametogenesis }\end{array}$ \\
\hline Male-based & 1R01OD028223-01 & $\begin{array}{l}\text { Derivation of Functional Spermatogonia Stem Cells From } \\
\text { Rhesus Macaque Ipscs }\end{array}$ \\
\hline Male-based & 1R01ES030942-01 & $\begin{array}{l}\text { Determining How Preconception Exposure to Phthalates } \\
\text { Impacts Sperm Function, the }\end{array}$ \\
\hline Female-based & 1R21ES026454-01A1 & $\begin{array}{l}\text { Detrimental Effects on Female Reproduction of in Utero and } \\
\text { Neonatal Exposure to Common Phthalates DEHP and Its } \\
\text { Replacement DINP }\end{array}$ \\
\hline Male-based & 1R21HD092700-01 & $\begin{array}{l}\text { Developing an Animal Model to Identify the Role of the Sperm } \\
\text { Centriole in Fertility }\end{array}$ \\
\hline Female-based & 1R61HD099742-01 & $\begin{array}{l}\text { Developing Modulators of the Sperm-specific Potassium } \\
\text { Channel Slo3 for Contraception }\end{array}$ \\
\hline Female-based & 1R43HD094454-01A1 & Development of a Biologic for Non-hormonal Contraception \\
\hline Male-based & 1R21HD083616-01A1 & $\begin{array}{l}\text { Development of a Zebrafish Model for Selenoprotein Synthesis } \\
\text { and Function }\end{array}$ \\
\hline Male-based & 1R61HD099720-01 & $\begin{array}{l}\text { Development of Allosteric Hipk4 Inhibitors as Non- } \\
\text { hormonal Male Contraceptives }\end{array}$ \\
\hline Female-based & 1R21HD092739-01 & Development of New Therapeutic Strategies for Endometriosis \\
\hline Not-Specified & 1R56HD095629-01 & Development of Novel Sperm-binding Antibodies \\
\hline Not-Specified & 1R01HD084380-01A1 & $\begin{array}{l}\text { Developmental Epidemiological Study of Children Born Through } \\
\text { Reproductive Technology (Descrt) }\end{array}$ \\
\hline Not-Specified & 1R21ES024854-01A1 & Dioxin and Estradiol Regulation of Proteins Through Cugbp2 \\
\hline Not-Specified & 1R01GM121688-01 & $\begin{array}{l}\text { Dissecting the Origins of a Complex Reproductive Trait: } \\
\text { Nematode Self Fertility }\end{array}$ \\
\hline Male-based & 1R43HD097820-01 & $\begin{array}{l}\text { Drug Interactions in Vitro for Ep055: a Non-hormonal Male } \\
\text { Contraceptive }\end{array}$ \\
\hline Female-based & 1R01HD091848-01A1 & Dynamic Regulation of the Ovarian Reserve \\
\hline Male-based & 1F32GM130006-01 & $\begin{array}{l}\text { Elucidating the Role of Small Rna Pathways in Heat-stress } \\
\text { Induced DNA Damage During Spermatogenesis }\end{array}$ \\
\hline Male-based & 1F30HD097961-01 & $\begin{array}{l}\text { Elucidating the Role of Tcf } 21+\text { Mesenchymal Cells in Testis } \\
\text { Tissue Homeostasis and Regeneration }\end{array}$ \\
\hline Male-based & 1R21ES026778-01A1 & $\begin{array}{l}\text { Embryonic Inheritance of Sperm Methylome After Adult } \\
\text { Exposure to Phthalates }\end{array}$ \\
\hline Female-based & 1R01ES026998-01A1 & $\begin{array}{l}\text { Environmentally Relevant Phthalate Exposures and Ovarian } \\
\text { Function }\end{array}$ \\
\hline Male-based & 1R01GM122776-01A1 & $\begin{array}{l}\text { Epigenetic Regulation of Gene Expression During } \\
\text { Spermatogenesis }\end{array}$ \\
\hline Male-based & 1F32HD086939-01A1 & Epigenetic Regulation of Histone Eviction in Spermatogenesis \\
\hline
\end{tabular}


bioRxiv preprint doi: https://doi.org/10.1101/2021.08.23.456936; this version posted August 24, 2021. The copyright holder for this preprint (which was not certified by peer review) is the author/funder, who has granted bioRxiv a license to display the preprint in perpetuity. It is made Female-based 1F32HD095618-01 able under accithelial Regeneration in the Adult Oviduct

\begin{tabular}{|c|c|c|}
\hline Male-based & 1F32HD097932-01A1 & $\begin{array}{l}\text { Examining the Androgenic and Progestational Effects of Novel } \\
\text { Androgens for Male Contraception }\end{array}$ \\
\hline Male-based & 1R01HD094698-01A1 & $\begin{array}{l}\text { Exploring Vascular-mesenchymal Interactions in the Stem Cell } \\
\text { Niche }\end{array}$ \\
\hline Not-Specified & 1R01HD089932-01A1 & Fa DDR Pathway in Germ Line Integrity \\
\hline Male-based & 1R21HD094322-01 & $\begin{array}{l}\text { Feasibility of in-home Semen Testing in a North American } \\
\text { Preconception Cohort Study }\end{array}$ \\
\hline Female-based & 1R03HD097262-01 & $\begin{array}{l}\text { Fertility Preservation in Women With Cystic Fibrosis Pre-lung } \\
\text { Transplantation }\end{array}$ \\
\hline Female-based & 1R56HD086054-01A1 & FSH and IGF1R Signaling Crosstalk in Ovarian GCS \\
\hline Male-based & 1R15GM126458-01 & Functional Analysis of MicroRNAs in C.elegans Spermatogenesis \\
\hline Male-based & 1R01HD088412-01 & $\begin{array}{l}\text { Functional Analysis of Novel Testis-expressed Secreted and } \\
\text { Transmembrane Proteins }\end{array}$ \\
\hline Female-based & 1R01ES029464-01A1 & $\begin{array}{l}\text { Functional and Epigenetic Effects of Preconceptional EDCs on } \\
\text { the Female HPG Axis }\end{array}$ \\
\hline Not-Specified & 1P01HD087157-01A1 & $\begin{array}{l}\text { Functional Genomics and Dec-tec to Identify Germ Cell-specific } \\
\text { Contraceptives }\end{array}$ \\
\hline Male-based & 1R01HD095341-01 & $\begin{array}{l}\text { Functional Genomics and Proteomics to Reveal Reproductive- } \\
\text { tract Specific Proteins }\end{array}$ \\
\hline Not-Specified & 1R01GM117155-01 & Functions of Polo-like Kinases During Mammalian Meiosis \\
\hline Male-based & 1R01ES030722-01A1 & $\begin{array}{l}\text { Genetic and Epigenetic Mechanisms of Infertility Caused by } \\
\text { Endocrine Disrupting Chemicals }\end{array}$ \\
\hline Female-based & 1R01HD086175-01A1 & $\begin{array}{l}\text { Genetic Interrogation of Conserved Follicular Factors for Matrix } \\
\text { Metalloproteinase Regulation and Ovulation }\end{array}$ \\
\hline Female-based & 1R21HD087427-01A1 & $\begin{array}{l}\text { Genetic Studies of the Kit Receptor Tyrosine Kinase in } \\
\text { Primordial Follicle Activation }\end{array}$ \\
\hline Female-based & 1R01HD093778-01 & $\begin{array}{l}\text { Genetics and Genomics of the Ovarian Reserve and Female } \\
\text { Fertility }\end{array}$ \\
\hline Female-based & 1R21HD087973-01 & $\begin{array}{l}\text { Genome-wide Identification of Genes Required for } \\
\text { Decidualization }\end{array}$ \\
\hline Female-based & 1F31HD088053-01 & $\begin{array}{l}\text { Genotoxic Effects of L1 Retrotransposition Trigger Oocyte } \\
\text { Elimination During MPI }\end{array}$ \\
\hline Not-Specified & 1R21AA024889-01A1 & Germ Cell Mediated Epigenetic Memory of Ethanol Exposure \\
\hline Female-based & 4R0OHD080742-03 & Greb1 Action in Endometrial Function and Dysfunction \\
\hline Male-based & 1R21ES027117-01 & Histone Lysine Crotonylation in Paternal Epigenetic Inheritance \\
\hline Female-based & 1R01HD093726-01 & $\begin{array}{l}\text { Homeostatic to Reactive Hyaluronan Matrices in Ovarian } \\
\text { Reproductive Aging }\end{array}$ \\
\hline Male-based & 1R01ES025066-01A1 & $\begin{array}{l}\text { Human Pesticide Exposure and Epigenetic Changes in Sperm } \\
\text { DNA }\end{array}$ \\
\hline Male-based & 1R03HD097433-01 & $\begin{array}{l}\text { Identification of Genetic Factors Contributing to Germline Stem } \\
\text { Cell Maintenance }\end{array}$ \\
\hline Male-based & 1R21HD086839-01A1 & Identification of Phospho-proteins Regulating Sperm Function \\
\hline Not-Specified & 1R01ES027921-01A1 & $\begin{array}{l}\text { Identity, Mechanisms and Early Life Impacts of Transporter } \\
\text { Interfering Compounds }\end{array}$ \\
\hline Not-Specified & 1F32HD094500-01 & $\begin{array}{l}\text { Improving Bovine Cloning Efficiency by Enhancing } \\
\text { Reprogramming During Embryonic Genome Activation (EGA) }\end{array}$ \\
\hline Female-based & 1R01HD089957-01 & $\begin{array}{l}\text { Improving Emergency Contraceptive Effectiveness in Obese } \\
\text { Women }\end{array}$ \\
\hline Male-based & 1R01HD092084-01 & Improving Fertility Preservation in Boys With Cancer \\
\hline Not-Specified & 1R01EB027099-01 & In Vivo Analysis of Mammalian Fertilization \\
\hline
\end{tabular}


bioRxiv preprint doi: https://doi.org/10.1101/2021.08.23.456936; this version posted August 24, 2021. The copyright holder for this preprint (which was not certified by peer review) is the author/funder, who has granted bioRxiv a license to display the preprint in perpetuity. It is made

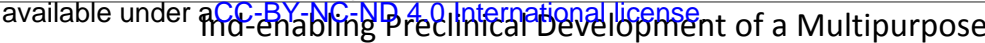

Female-based 1R61Al136008-01 Intravaginal Ring for the Prevention of Herpes, HIV and Unintended Pregnancy

Female-based 2R44Al124815-02A1 Ind-enabling Preclinical Development of a System for the Multipurpose Prevention of HIV and Unintended Pregnancy

Female-based 4R00NR017191-02 Influence of Diet, Iron Stores, and Toxic Metals on Uptakes and Effects on Uterine Fibroid Risk in African American Women

Female-based 1R41HD100190-01
Innovative 3d Printed Intravaginal Ring Anelleo-pro, the First Single Administration of Progesterone for Infertility

\begin{tabular}{ll}
\hline Female-based & 1R21HD097601-01 \\
\hline Female-based & 1R21ES026282-01A1 \\
\hline
\end{tabular}

Male-based 1F31GM117971-01

Female-based 5F31HD096838-01 Integrative Metabolism of Oocyte Development and Its Modulation by Maternal Diet Investigating Modes of Action of Glyphosate-induced Ovotoxicity Investigating the Functional Role of Zinc Fluxes During Sperm Activation

\begin{tabular}{|c|c|c|}
\hline Female-based & 5F31HD096838-01 & $\begin{array}{l}\text { Investigating the Role of an FSHB Enhancer in FSHB Expression } \\
\text { and Polycystic Ovary Syndrome }\end{array}$ \\
\hline Male-based & 3R01HD091068-03S1 & IPSC-derived Organoids to Study Testis Function \\
\hline Male-based & 1R03HD094046-01 & $\begin{array}{l}\text { Isolation of Viable Human Sperm From Failed Microsurgical } \\
\text { Testicular Biopsies }\end{array}$ \\
\hline Male-based & 1R03HD099412-01 & L1 Retrotansposition During Spermatogenic Failure \\
\hline Female-based & 1R01HD093671-01 & $\begin{array}{l}\text { Large-scale Studies in Emerge to Discover the Genetic } \\
\text { Determinants of Uterine Fibroids }\end{array}$ \\
\hline Male-based & 1R03HD090315-01 & $\begin{array}{l}\text { Lifestyle and Psychosocial Determinants of Male Subfertility: a } \\
\text { Prospective Study }\end{array}$ \\
\hline Male-based & 1R01HD084353-01A1 & $\begin{array}{l}\text { Linking Fertility-associated Gene Polymorphisms to Aberrant } \\
\text { Sperm Phenotypes }\end{array}$ \\
\hline Female-based & 1R61Al142687-01 & $\begin{array}{l}\text { Long Acting Film Technology for Contraception and HIV } \\
\text { Prevention (Latch) }\end{array}$ \\
\hline Male-based & 1R44HD099040-01 & $\begin{array}{l}\text { Low Cost, Automated Smartphone Based Assay for Semen } \\
\text { Analysis }\end{array}$ \\
\hline Male-based & 1R44HD093493-01 & $\begin{array}{l}\text { Low-cost, Portable and Automated Semen Analysis Using } \\
\text { Computational Microscopy for Home-based Testing of Male } \\
\text { Wellness and Fertility }\end{array}$ \\
\hline Male-based & 1R35GM119458-01 & Macrophage Regulation of the Spermatogonial Stem Cell Niche \\
\hline Male-based & 1R01ES028214-01 & $\begin{array}{l}\text { Male Preconception Phthalates and Offspring Embryo and } \\
\text { Sperm Allele-specific Methylome Programming }\end{array}$ \\
\hline Male-based & $\begin{array}{l}\text { 1P01HD087157-01A1 } \\
8121\end{array}$ & $\begin{array}{l}\text { Manipulation of Sperm-specific Proteases Using Genetic and } \\
\text { Chemical Approaches }\end{array}$ \\
\hline Female-based & 1R35GM131810-01 & Maternal Control of Germline Development \\
\hline Not-Specified & 1R35GM118092-01 & Mechanism and Regulation of Meiotic Recombination \\
\hline Not-Specified & 3R01DK047320-22S2 & Mechanism of Selenoprotein Synthesis \\
\hline Female-based & 1R01GM124519-01A1 & $\begin{array}{l}\text { Mechanisms Driving the Transition From Oocyte to Embryo: the } \\
\text { Role of the mRNA Decay Activator Zfp } 3612\end{array}$ \\
\hline Female-based & 1F30HD100126-01 & $\begin{array}{l}\text { Mechanisms Linking Global Transcriptional Silencing and Zygotic } \\
\text { Gene Activation During the Oocyte-to-embryo Transition in } \\
\text { Mammals }\end{array}$ \\
\hline Male-based & 4R0OHD081204-02 & $\begin{array}{l}\text { Mechanisms of a Novel Actin Related Protein in Male Gametes } \\
\text { Ensuring Fertility }\end{array}$ \\
\hline Not-Specified & 1R01ES027487-01 & $\begin{array}{l}\text { Mechanisms of Memory of Environmental Exposure: } \\
\text { Determining the Role of Histone Modifications in Regulating } \\
\text { Transgenerational Behavior Effects Caused by Environmental } \\
\text { Chemical Exposure. }\end{array}$ \\
\hline
\end{tabular}


bioRxiv preprint doi: https://doi.org/10.1101/2021.08.23.456936; this version posted August 24, 2021. The copyright holder for this preprint (which was not certified by peer review) is the author/funder, who has granted bioRxiv a license to display the preprint in perpetuity. It is made

\begin{tabular}{|c|c|c|}
\hline Not-Specified & 1R15HD095735-01 & 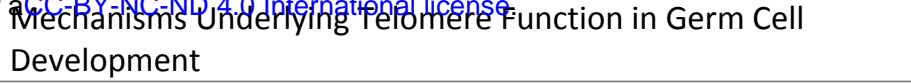 \\
\hline Female-based & 1R03HD087528-01A1 & $\begin{array}{l}\text { Membrane Estrogen Receptor } 1 \text { Mediation of Epigenetic Effects } \\
\text { of Estrogen }\end{array}$ \\
\hline Male-based & 1R01HD093827-01A1 & Membrane Lipid Regulation of Calcium Channels in Sperm. \\
\hline Female-based & 1R01HD087402-01A1 & Metabolic Events Controlling Ovarian Steroidogenesis \\
\hline Female-based & 1R01HD092263-01 & Metabolic Regulators of Corpus Luteum Function \\
\hline Male-based & 1R01GM132490-01 & $\begin{array}{l}\text { Mitochondria-anchored Protein Complexes in piRNA Biogenesis } \\
\text { and Function }\end{array}$ \\
\hline Female-based & 1F32HD095550-01 & $\begin{array}{l}\text { Modelling Human Embryonic Aneuploidy Using Pre- } \\
\text { implantation Bovine Embryos }\end{array}$ \\
\hline Female-based & 1F30AG058387-01A1 & $\begin{array}{l}\text { Modelling Ovarian Ageing Phenotype in Mechanically Tuned 3d } \\
\text { Matrices }\end{array}$ \\
\hline Female-based & 5F30DK108561-02 & $\begin{array}{l}\text { Molecular and Cellular Changes in the Peritoneal Surface } \\
\text { Mesothelium During Adhesion Formation }\end{array}$ \\
\hline Female-based & 1R21HD094096-01 & $\begin{array}{l}\text { Molecular Identity of Maternal Regulators of the Egg to Embryo } \\
\text { Transition }\end{array}$ \\
\hline Male-based & 1R03HD098314-01A1 & $\begin{array}{l}\text { Molecular Marker for Centriole Remodelling in Human } \\
\text { Reproduction }\end{array}$ \\
\hline Female-based & 1R35GM122580-01 & Molecular Mechanisms of the Maternal to Zygotic Transition \\
\hline Female-based & 1R43HD097720-01 & $\begin{array}{l}\text { Multi-center Prospective Study Assessing a Panel of MicroRNAs } \\
\text { as a Non-invasive Test for Endometriosis }\end{array}$ \\
\hline Female-based & 1R01HD086100-01A1 & Neuroendocrine Regulation of Reproduction by Glucocorticoids \\
\hline Female-based & 1R01HD097675-01A1 & Neurotensin: a Novel Mediator of Ovulation \\
\hline Female-based & 1R61HD099747-01 & $\begin{array}{l}\text { Nonhormonal Contraceptive Intravaginal Ring Based on High } \\
\text { Valency Anti-Sperm Antibody Constructs }\end{array}$ \\
\hline Female-based & 1R43HD097941-01 & $\begin{array}{l}\text { Non-hormonal Contraception Based on Vaginal Delivery of } \\
\text { Multimeric Sperm-binding Antibodies }\end{array}$ \\
\hline Female-based & 1R03HD098441-01 & $\begin{array}{l}\text { Novel Reverse Genetics Approach to Probe Cytoskeletal } \\
\text { Functions in Mammalian Oocytes }\end{array}$ \\
\hline Male-based & 1R01HD090007-01 & $\begin{array}{l}\text { Origin and Functional Significance of the Spermatogonial Stem } \\
\text { Cell Transcriptome Barcode }\end{array}$ \\
\hline Female-based & 1R21HD094983-01 & $\begin{array}{l}\text { Oxygen as a Potential Regulator of Follicle Quiescence in the } \\
\text { Primate Ovary }\end{array}$ \\
\hline Female-based & 1R03HD090624-01A1 & $\begin{array}{l}\text { P21-activated Kinase as Regulator of Actin and Microtubules in } \\
\text { Mammalian Oocytes }\end{array}$ \\
\hline Female-based & 6R21HD080148-02 & $\begin{array}{l}\text { Parous Mouse: a Unique Model to Define Uterine Receptivity } \\
\text { Versus Nonreceptivity }\end{array}$ \\
\hline Male-based & 1R01ES028298-01A1 & $\begin{array}{l}\text { Paternal Preconception Phthalates and Reproductive Health - } \\
\text { Potential Mediation Through Sperm DNA Methylation }\end{array}$ \\
\hline Female-based & 1F32HD097939-01 & $\begin{array}{l}\text { Paxillin as a Mediator of Non-classical Androgen Receptor } \\
\text { Actions in Ovarian Follicles }\end{array}$ \\
\hline Not-Specified & 5R01HD086478-03 & $\begin{array}{l}\text { Phenotyping Early Embryonic Lethal Knockout Mice to Identify } \\
\text { Essential Genes With Previously Uncharacterized Roles in Pre- } \\
\text { implantation Development, Gastrulation, Turning, and } \\
\text { Placentation }\end{array}$ \\
\hline Female-based & 1K99ES028748-01 & Phthalate-induced Ovulatory Dysfunction in Women \\
\hline Female-based & 4R00ES028748-03 & Phthalate-induced Ovulatory Dysfunction in Women \\
\hline Female-based & 1R56ES025147-01A1 & Phthalates and Ovarian Toxicity \\
\hline Female-based & 1R01ES028661-01A1 & Phthalates and Ovarian Toxicity \\
\hline Female-based & 1R56ES025728-01A1 & $\begin{array}{l}\text { Placental Molecule Secretions Measured in Early Pregnancy Are } \\
\text { Targets of Endocrine Disruption and Are Indicators of Sex- } \\
\text { specific Fetal Development }\end{array}$ \\
\hline
\end{tabular}


bioRxiv preprint doi: https://doi.org/10.1101/2021.08.23.456936; this version posted August 24, 2021. The copyright holder for this preprint (which was not certified by peer review) is the author/funder, who has granted bioRxiv a license to display the preprint in perpetuity. It is made

\begin{tabular}{ll}
\hline Female-based & available under \\
& 1R43HD097944-01 \\
\hline Not-Specified & 1R01HD083260-01A1 \\
\hline Female-based & 1R43AI124815-01
\end{tabular}

Female-based 1R01HD100336-01 Nonhormonal Female Contraceptive Postnatal Plasticity in the GNRH System Preclinical Development of a Multipurpose Intravaginal Ring for the Prevention of HIV and Unintended Pregnancy Pre-IVF Treatment With a GNRH Antagonist in Women With

Female-based 1 R01
$\begin{array}{lll}\text { Female-based } & \text { 1R01HD100329-01 } & \text { Endometriosis - a Prospective Do } \\ & & \text { Trial (Pregnant) - Application 4/4 }\end{array}$ Endometriosis - a Prospective Double Blind Placebo Controlled Trial (Pregnant) - Application 1/4 Pre-IVF Treatment With a GNRH Antagonist in Women With

\begin{tabular}{ll}
\hline Female-based & 1R01HD100343-01 \\
\hline Female-based & 1R01HD099487-01 \\
\hline Male-based & 1R01HD095631-01 \\
\hline Male-based & 5R01HD095630-02 \\
\hline
\end{tabular}
Pre-IVF Treatment With a GNRH Antagonist in Women With Endometriosis - a Prospective Double Blind Placebo Controlled Trial 2/3 Primary Ovarian Insufficiency: Etiology and Comorbid Disease Project One: Development and Testing of Hca Ivr Project Three: Assessing Effects of Anti-CD52G MABS on STD Pathogens in Semen

Female-based 1R21HD091337-01 Prospective Randomized Trial of Tranexamic Acid Versus Levonorgestrel Intrauterine System for the Treatment of Heavy Menstrual Bleeding in Women With Uterine Fibroids

\begin{tabular}{|c|c|c|}
\hline Female-based & 1R01HD092499-01A1 & $\begin{array}{l}\text { Regulation of Ca2+ Influx in Mouse Oocytes and Eggs During } \\
\text { Maturation and Fertilization to Improve Assisted Reproductive } \\
\text { Technologies and Modulate Fertility }\end{array}$ \\
\hline Not-Specified & 1R01GM123556-01A1 & Regulation of Developmental Potency by the Transposon Line1 \\
\hline Male-based & 1R35GM118052-01 & Regulation of Meiosis in Mice \\
\hline Female-based & 1R15HD099859-01 & Regulation of Oocyte Development by Steroid Hormones \\
\hline Not-Specified & 1R01GM113001-01A1 & $\begin{array}{l}\text { Regulation of Sex-specific Gonad Stem Cell Niche Development } \\
\text { by Doublesex }\end{array}$ \\
\hline Male-based & 1R03HD096176-01 & $\begin{array}{l}\text { Regulation of Sperm Metabolism and Fertility by Calcineurin } \\
\text { and Gsk3 }\end{array}$ \\
\hline Male-based & 1F31HD097928-01A1 & $\begin{array}{l}\text { Replication-independent DNA Methylation Dynamics During } \\
\text { Post-Testicular Sperm Maturation }\end{array}$ \\
\hline Male-based & 1R01GM124024-01 & $\begin{array}{l}\text { Requirements for Cytosolic Chaperones in the De Novo Folding } \\
\text { of Septin Proteins }\end{array}$ \\
\hline Male-based & 4R00ES025231-03 & $\begin{array}{l}\text { Retinoic Acid Signaling Disruption by Phthalates in Human and } \\
\text { Rodent Fetal Testis }\end{array}$ \\
\hline Male-based & 1K99ES025231-01A1 & $\begin{array}{l}\text { Retinoic Acid Signaling Disruption by Phthalates in Human and } \\
\text { Rodent Fetal Testis }\end{array}$ \\
\hline Female-based & 1R01HD098200-01 & Reversible Contraception by Selective Silencing of GNRH-II \\
\hline Female-based & 1R01HD084478-01A1 & Risk Factors for Early Pregnancy Loss \\
\hline Male-based & 1R01HD094546-01A1 & $\begin{array}{l}\text { Rna Pol II Pausing Is Critical for Spermatogenesis and Male } \\
\text { Fertility }\end{array}$ \\
\hline Not-Specified & 1R01GM125800-01 & $\begin{array}{l}\text { Role of Chromosomally Tethered Proteasome in Chromosome } \\
\text { Pairing and Meiotic Recombination }\end{array}$ \\
\hline Not-Specified & 1R01GM127569-01A1 & Role of GCNA in Preserving Genome Integrity and Fertility \\
\hline Female-based & 1R01HD089495-01A1 & Role of Neuroestradiol in Regulation of the GNRH Surge \\
\hline Female-based & 1R56HD093383-01A1 & Role of the DNA Helicase LSH in Female Meiosis \\
\hline Male-based & 1R01HD093703-01A1 & $\begin{array}{l}\text { Role of the Extracellular Matrix During Wolffian/epididymal } \\
\text { Duct Morphogenesis }\end{array}$ \\
\hline Male-based & 1R01HD094736-01A1 & Roles of X-and Y-palindromic Genes in Mammalian Fertility \\
\hline Female-based & 1R44HD095724-01 & Safety, and Acceptability of a Non-hormonal Vaginal Ring \\
\hline Female-based & 1R01HD097202-01A1 & Salt-inducible Kinase Regulation of Ovarian Granulosa Cells \\
\hline
\end{tabular}


bioRxiv preprint doi: https://doi.org/10.1101/2021.08.23.456936; this version posted August 24, 2021. The copyright holder for this preprint (which was not certified by peer review) is the author/funder, who has granted bioRxiv a license to display the preprint in perpetuity. It is made Female-based 1R01GM129478-01

\begin{tabular}{|c|c|c|}
\hline Female-based & 1R44HD097750-01 & $\begin{array}{l}\text { Sirt1 and Bcl6: Dual Biomarkers of Endometriosis and } \\
\text { Endometrial Receptivity }\end{array}$ \\
\hline Not-Specified & 1R01HD095628-01 & Slo3 K Channel: a Novel Target for Contraception \\
\hline Female-based & 1R61HD099748-01 & $\begin{array}{l}\text { Smart Polymer Fibers for Tampon-like Nonsteroidal } \\
\text { Contraceptive Devices }\end{array}$ \\
\hline Not-Specified & 1R15GM117548-01 & $\begin{array}{l}\text { Specification of Meiotic Cohesin Function by Divergent Alpha- } \\
\text { kleisin Subunits }\end{array}$ \\
\hline Male-based & 1R44HD095355-01 & Sperm Sample Preparation for Point of Care Applications \\
\hline Female-based & 1R21HD092009-01 & $\begin{array}{l}\text { Stem Cell-derived GNRH Neurons: Optimization and } \\
\text { Characterization }\end{array}$ \\
\hline Female-based & 1R01HD088638-01 & Study of Ovarian Aging and Reserve in Young Women (Soar) \\
\hline Female-based & 1R61HD099745-01 & Synthetic mRNA-mediated Reversible Immunocontraception \\
\hline Not-Specified & 1K99ES025280-01A1 & $\begin{array}{l}\text { Systems Approach to Define AHR Ligand Toxicity on } \\
\text { Reproductive System Development }\end{array}$ \\
\hline Male-based & $\begin{array}{l}\text { 1P01HD087157-01A1 } \\
8119\end{array}$ & $\begin{array}{l}\text { Targeting Sperm-specific Proteins During Meiosis and Sperm } \\
\text { Morphogenesis }\end{array}$ \\
\hline Male-based & 1R61HD099722-01 & $\begin{array}{l}\text { Targeting Testis-specific Ubiquitin-proteasome Pathways for } \\
\text { Male Contraception }\end{array}$ \\
\hline Female-based & 1R01HL134840-01 & Telomeres and Fecundity \\
\hline Female-based & 1R01HD097087-01 & The Actions of Steroid Hormones on Oviduct Function \\
\hline Male-based & 1R01ES028712-01 & $\begin{array}{l}\text { The Effects of Environmental Exposures on Semen Quality and } \\
\text { the Sperm Epigenome }\end{array}$ \\
\hline Female-based & 1R03HD095098-01 & $\begin{array}{l}\text { The Function of Progesterone Receptor in Human Ovulatory } \\
\text { Follicles }\end{array}$ \\
\hline Female-based & 1F32HD098805-01 & $\begin{array}{l}\text { The Homeodomain Transcription Factors, Six } 6 \text { and Six } 3 \text {, in the } \\
\text { Circadian Regulation of Reproduction }\end{array}$ \\
\hline Not-Specified & 7R21HD088792-02 & $\begin{array}{l}\text { the Impact of Piwi Associated Transcripts in Xenopus Germ Cell } \\
\text { Development }\end{array}$ \\
\hline Female-based & 1R15HD087911-01 & $\begin{array}{l}\text { The Interaction Between Nat2 Acetylator Status and Exposure } \\
\text { to Tobacco Smoke on Ovarian Reserve and in Vitro Fertilization } \\
\text { Outcomes. }\end{array}$ \\
\hline Female-based & 1R01HD091117-01A1 & $\begin{array}{l}\text { The Oocyte's Progression Through Meiosis: Involvement of a } \\
\text { Heart Disease-associated Protein }\end{array}$ \\
\hline Female-based & 1R01HD096077-01A1 & The Role of FOS in the Ovary \\
\hline Male-based & 1R03HD090306-01 & $\begin{array}{l}\text { the Role of Transcription Factor S-sox5 in Male Fertility and } \\
\text { Sperm Flagella Formation }\end{array}$ \\
\hline Female-based & 1R21HD094293-01A1 & Timing Endometrial Receptivity \\
\hline Female-based & 1R01HD098278-01 & $\begin{array}{l}\text { Towards a Preclinical Model for Overcoming Infertility With } \\
\text { Induced Pluripotent Stem Cells }\end{array}$ \\
\hline Female-based & 3R01ES027051-02S1 & $\begin{array}{l}\text { Transdisciplinary Approach to Rapidly Identify Reproductive } \\
\text { Toxics in Pregnant Women and Newborns }\end{array}$ \\
\hline Male-based & 1R03ОН011540-01 & Transgenerational Work Exposures, EDCs and Male Fertility \\
\hline Male-based & 1R44HD100256-01 & $\begin{array}{l}\text { Translational Feasibility of an Oral, Non-hormonal, Male } \\
\text { Contraceptive Pill }\end{array}$ \\
\hline Male-based & 1R56AG052581-01A1 & $\begin{array}{l}\text { Tumor Suppressors Mediate a Reduction in Male Gamete } \\
\text { Quality With Aging }\end{array}$ \\
\hline Female-based & 1R21ES028963-01A1 & Water Disinfection by-products and Female Fertility \\
\hline Male-b & 1R01GM130691-01 & Chromosome Evolution \\
\hline
\end{tabular}

Supplementary Table VII - Research project titles from the NIH (US) funding agencies. Some projects titles are repeated; however they would have separate grants awarded under different project IDs. Further information on each research project can be found in NIH Dataset_EG_CDJ_CLRB. 
bioRxiv preprint doi: https://doi.org/10.1101/2021.08.23.456936; this version posted August 24, 2021. The copyright holder for this preprint (which was not certified by peer review) is the author/funder, who has granted bioRxiv a license to display the preprint in perpetuity. It is made available under aCC-BY-NC-ND 4.0 International license.

\begin{tabular}{|c|c|}
\hline HRCS Health Categories & Total Funding Awarded (f) \\
\hline Mental Health & $493,552,549$ \\
\hline Generic Health Relevance & $484,950,225$ \\
\hline Cancer and Neoplasms & $347,947,217$ \\
\hline Infection & $275,265,348$ \\
\hline Cardiovascular & $224,898,509$ \\
\hline Neurological & $222,002,645$ \\
\hline Reproductive Health and Childbirth & $216,618,019$ \\
\hline Oral and Gastrointestinal & $164,146,703$ \\
\hline Respiratory & $146,665,215$ \\
\hline Metabolic and Endocrine & $129,821,105$ \\
\hline Musculoskeletal & $126,596,631$ \\
\hline Stroke & $121,450,341$ \\
\hline Injuries and Accidents & $119,415,772$ \\
\hline Renal and Urogenital & $108,827,444$ \\
\hline Skin & $66,127,071$ \\
\hline Eye & $63,433,235$ \\
\hline Inflammatory and Immune System & $54,122,033$ \\
\hline Blood & $29,836,676$ \\
\hline Disputed etiology and other & $23,847,721$ \\
\hline Congenital Disorders & $18,740,901$ \\
\hline Ear & $11,238,128$ \\
\hline
\end{tabular}

Supplementary Table VIII - The NIHR's Total Funding Awarded for the 21 health categories of research and specialties as of April $1^{\text {st }}, 2011$. The present data is extracted from the NIHR's Open Data. 
bioRxiv preprint doi: https://doi.org/10.1101/2021.08.23.456936; this version posted August 24, 2021. The copyright holder for this preprint (which was not certified by peer review) is the author/funder, who has granted bioRxiv a license to display the preprint in perpetuity. It is made Supplementary Table IX : Estimated Proportion of Funding to RCDC by the Nifise against the NIH's Total Budget

\begin{tabular}{|c|c|c|c|c|c|}
\hline \multirow{2}{*}{$\mathrm{RCDC}$} & & \multicolumn{4}{|c|}{ Fiscal Years } \\
\hline & & 2016 & 2017 & 2018 & 2019 \\
\hline \multirow{2}{*}{$\begin{array}{l}\text { Contraception/ } \\
\text { Reproduction }\end{array}$} & $\begin{array}{l}\text { Value } \\
(\$ 000)\end{array}$ & 419,000 & 437,000 & 496,000 & 547,000 \\
\hline & (\%) & 1.85 & 1.82 & 1.91 & 1.94 \\
\hline \multirow[t]{2}{*}{ Infertility } & $\begin{array}{l}\text { Value } \\
(\$ 000)\end{array}$ & 86,000 & 94,000 & 120,000 & 151,000 \\
\hline & (\%) & 0.38 & 0.39 & 0.46 & 0.54 \\
\hline \multirow[t]{2}{*}{ Obesity } & $\begin{array}{l}\text { Value } \\
(\$ 000)\end{array}$ & 965,000 & 999,000 & $1,055,000$ & $1,109,000$ \\
\hline & (\%) & 4.26 & 4.16 & 4.07 & 3.94 \\
\hline \multirow[t]{2}{*}{ Mental Health } & $\begin{array}{l}\text { Value } \\
(\$ 000)\end{array}$ & $2,454,000$ & $2,717,000$ & $3,010,000$ & $3,296,000$ \\
\hline & (\%) & 10.83 & 11.31 & 11.62 & 11.71 \\
\hline \multicolumn{2}{|c|}{$\begin{array}{l}\text { Total NIH Research Funding } \\
\text { (\$) }\end{array}$} & $22,649,752,290$ & $24,031,670,764$ & $25,906,788,735$ & $28,143,252,479$ \\
\hline
\end{tabular}

Supplementary Table IX: The NIH fund 299 various research, conditions, and diseases categories (RCDC) and a project can fall under multiple RCDCs as the NIH does not budget research per category NIH, 2021). The estimated proportion of funding for the chosen categories of contraception/ reproduction, infertility, obesity, and mental health against the annual NIH total research grant funding between FY2016 to FY2019. The FY2020 was excluded from this table as only 2 projects were collected and would be incomparable. Value $(\$ 000)$ refers to the estimated funding by the NIH RCDC Categorical Spending in millions. (\%) is the calculated funding percentage or proportion for the RCDCs from the annual NIH Total Research Funding 
bioRxiv preprint doi: https://doi.org/10.1101/2021.08.23.456936; this version posted August 24, 2021. The copyright holder for this preprint (which was not certified by peer review) is the author/funder, who has granted bioRxiv a license to display the preprint in perpetuity. It is made

Supplementary Figures:

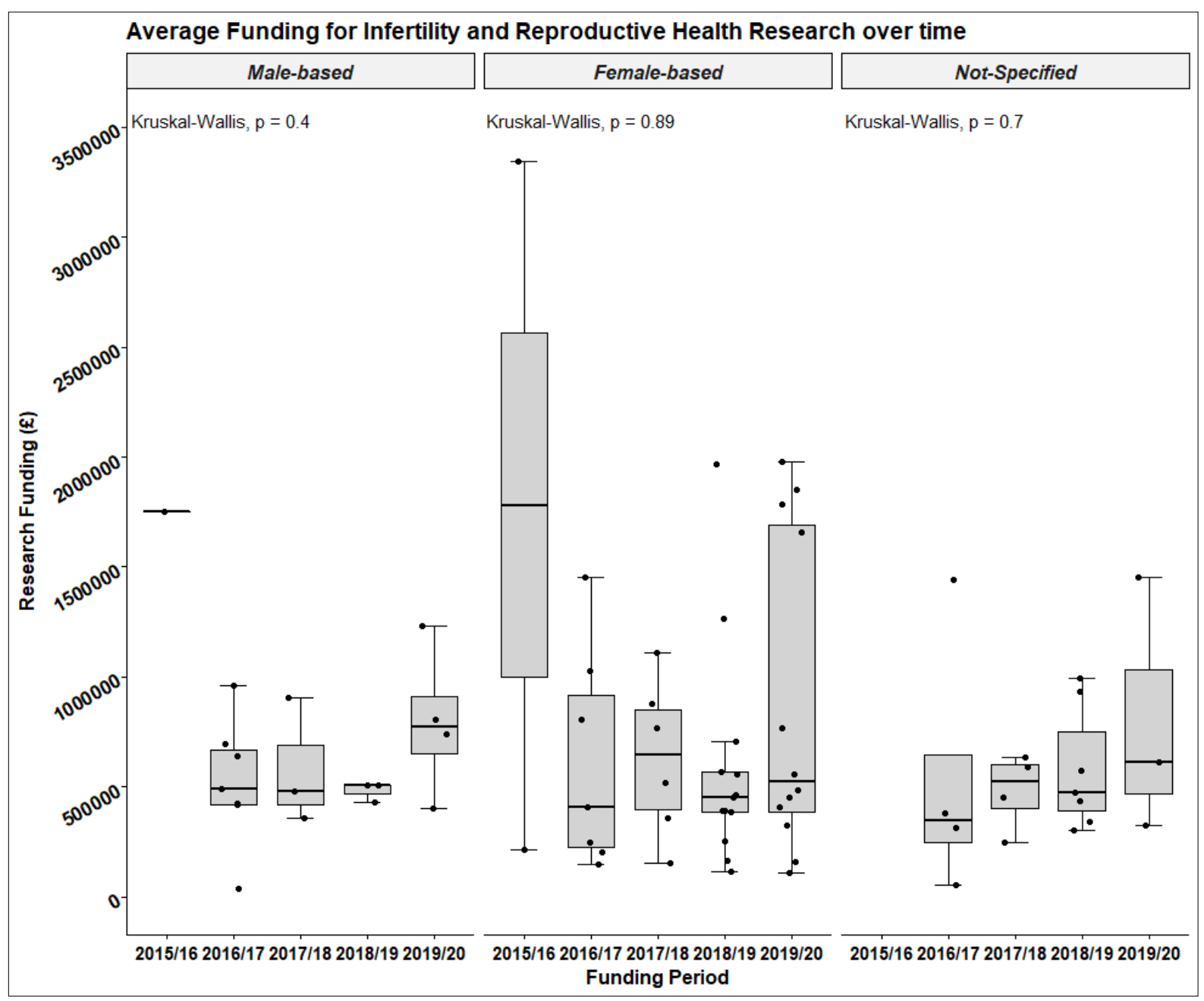

Supplementary Figure 1: The UK average funding across consecutive funding periods box-and-whisker plot with a $95 \% \mathrm{Cl} .3$ projects were collected between January $1^{\text {st }}$ to March $31^{\text {st }}, 2016$, for the 2015/16 funding period, therefore many projects were not expected to be awarded funding. No statistically significant differences of funding variation were observed by the Kruskal-Wallis test over the consecutive funding periods of each research group. In the male-based group, $\mathrm{P}=0.39$ and $\chi^{2}=4.08$ with 4 degrees of freedom. For the female-based group, $\mathrm{P}=0.89$ and $\chi^{2}=1.1$ with 4 degrees of freedom. In the not-specified group, $P=0.7$ and $\chi^{2}=1.41$ with 3 degrees of freedom. 
bioRxiv preprint doi: https://doi.org/10.1101/2021.08.23.456936; this version posted August 24, 2021. The copyright holder for this preprint (which was not certified by peer review) is the author/funder, who has granted bioRxiv a license to display the preprint in perpetuity. It is made

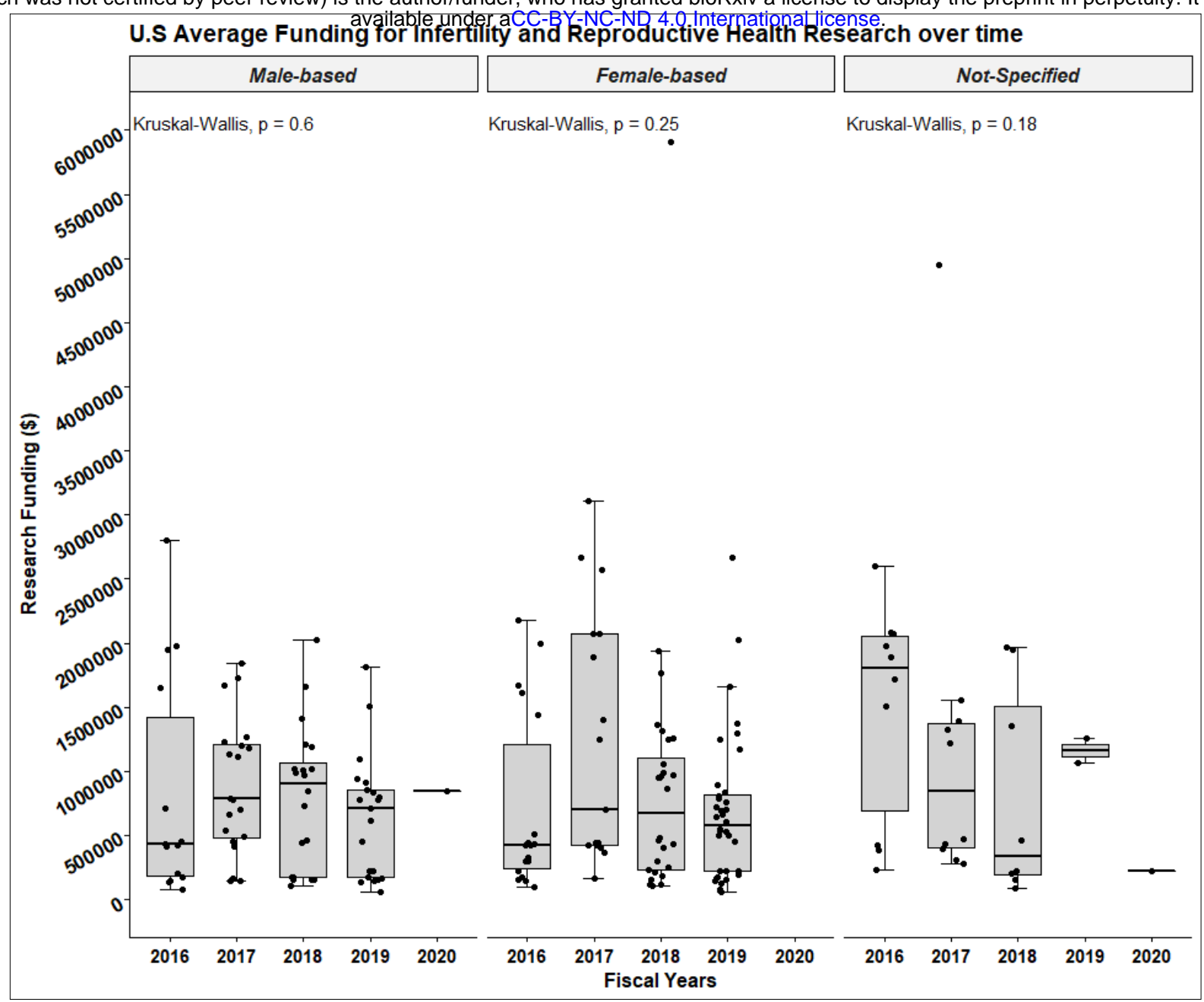

Supplementary Figure 2: Box-and-whisker plot has a $95 \% \mathrm{Cl}$ for the funding awarded across the five consecutive FYs by the NIH institutes. In the FY2020, 2 projects were awarded funding between $1^{\text {st }}$ October to $31^{\text {st }}$ December 2019. The Kruskal-Wallis did not observe statistically significant differences of funding variation over the consecutive FYs of each research group. For the male-based group, $\mathrm{P}=0.59$ and $\chi^{2}=2.76$ with 4 degrees of freedom. In the female-based group, $P=0.25$ and $\chi^{2}=4.12$ with 3 degrees of freedom. In the not-specified group, $P=0.18$ and $\chi^{2}=6.28$ with 4 degrees of freedom. 